\title{
Living (stained) foraminifera in the Lesser Syrtis (Tunisia): influence of pollution and substratum
}

\author{
Akram El Kateb ${ }^{1}$, Valentina Beccari $^{1}$, Stephanie Stainbank ${ }^{1}$, Silvia Spezzaferri ${ }^{\text {Corresp., }}{ }^{1}$, Giovanni Coletti $^{2}$ \\ 1 Department of Geosciences, University of Fribourg, Fribourg, Switzerland \\ 2 Department of Earth and Environmental Sciences, University of Milan - Bicocca, Milano, Italy \\ Corresponding Author: Silvia Spezzaferri \\ Email address: silvia.spezzaferri@unifr.ch
}

Foraminifera are protozoans with biomineralized tests that can be successfully used as a low cost monitoring tool to assess the health status of marine environments. Living benthic foraminiferal assemblages can provide essential information on natural and/or anthropogenic stresses and provide baseline conditions for studies on fossil material. Several studies have highlighted the negative impact of phosphate treatment industries along the Gulf of Gabes (Lesser Syrtis, Tunisia) on the marine environment. However, only few studies, based on living (stained) benthic foraminifera, are presently available to assess environmental and/or ecological conditions in this Gulf. Thirty-eight surface sediment samples were quantitatively investigated to identify the dominant living benthic foraminiferal species and potential pollution-sensitive and stress-tolerant species. Onehundred and sixty-one species were identified, and grouped into 7 clusters representing different environments within the Gulf. These groups represent polluted settings (Cluster A and B), polluted environments characterized by physicochemical variability (Cluster C), seagrass meadows and "pristine" sites (Cluster $D$ and $E$ ) and the region subjected to major industrial impact (Cluster F). The final outlier Cluster, identified the foraminifera barren and all shallow coastal stations. A SIMPER analysis helped identify species with clear and fast responses to environmental perturbations (Ammonia tepida, Amphistegina lessonii, Brizalina striatula, Bulimina marginata, Buliminella elegantissima, Eggereloides scaber, Peneroplis perutusus, Rosalina macropora, Rosalina villardeboana, Trochammina inflata). A comparison with the measured geochemical parameters (TOC, phosphorus in the sediments and heavy metal concentrations in the seawater) has shown that the benthic foraminiferal assemblages are mainly linked to phosphorus, TOC, As and Cd pollution. We provide here the first compilation of the identified living species in the Lesser Syrtis, their synonyms and digital images of important species. 
2 Living (stained) foraminifera in the Lesser Syrtis (Tunisia): influence of pollution and 3 substratum

4

$5 \quad$ Akram El Kateb $^{\mathrm{a}}$, Valentina Beccari ${ }^{\mathrm{a}}$, Stephanie Stainbank ${ }^{\mathrm{a}}$, Silvia Spezzaferria, Giovanni

6 Coletti $^{\mathrm{b}}$

7

8 a Department of Geosciences, University of Fribourg, Chemin du Musée 6, 1700 CH-1700

9 Fribourg, Switzerland.

$10 \mathrm{~b}$ Department of Earth and Environmental Sciences, University of Milano Bicocca, 20126, 11 Milano, Italy.

13 Corresponding author: Silvia Spezzaferri; silvia.spezzaferri@unifr.ch

15 Key Words: Foraminifera, Bioindicators, Taxonomy, Pollution, Tunisia,

18 ABSTRACT

Foraminifera are protozoans with biomineralized tests that can be successfully used as a low cost monitoring tool to assess the health status of marine environments. Living benthic foraminiferal assemblages can provide essential information on natural and/or anthropogenic stresses and provide baseline conditions for studies on fossil material. Several studies have highlighted the negative impact of phosphate treatment industries along the Gulf of Gabes 
24 (Lesser Syrtis, Tunisia) on the marine environment. However, only few studies, based on

25 living (stained) benthic foraminifera, are presently available to assess environmental and/or

26 ecological conditions in this Gulf. Thirty-eight surface sediment samples were quantitatively

27 investigated to identify the dominant living benthic foraminiferal species and potential

28 pollution-sensitive and stress-tolerant species. One-hundred and sixty-one species were

29 identified, and grouped into 7 clusters representing different environments within the Gulf.

30 These groups represent polluted settings (Cluster A and B), polluted environments

31 characterized by physicochemical variability (Cluster C), seagrass meadows and "pristine"

32 sites (Cluster D and E) and the region subjected to major industrial impact (Cluster F). The

33 final outlier Cluster, identified the foraminifera barren and all shallow coastal stations. A

34 SIMPER analysis helped identify species with clear and fast responses to environmental

35 perturbations (Ammonia tepida, Amphistegina lessonii, Brizalina striatula, Bulimina

36 marginata, Buliminella elegantissima, Eggereloides scaber, Peneroplis perutusus, Rosalina

37 macropora, Rosalina villardeboana, Trochammina inflata). A comparison with the

38 measured geochemical parameters (TOC, phosphorus in the sediments and heavy metal

39 concentrations in the seawater) has shown that the benthic foraminiferal assemblages are

40 mainly linked to phosphorus, TOC, As and Cd pollution. We provide here the first

41 compilation of the identified living species in the Lesser Syrtis, their synonyms and digital

42 images of important species. 


\section{INTRODUCTION}

51 The phosphate treatment industry started in Tunisia (Lesser Syrtis) in the second half of the $20^{\text {th }}$

52 century. The high degree of pollution generated by this industry, within the Gulf of Gabes, is

53 well documented. As a result of

54 this phosphate pollution, the marine environment within the Gulf of Gabes has been deeply

55 affected since the beginning of the industrial exploitations. The first production unit was created

56 at Sfax in 1952, followed by the industrial complex of Gabes in 1972, while the last industrial

57 complex was created at Skhira in 1988. These industries generate a large amount of waste

58 products e.g., phosphogypsum (PG). For each ton of phosphoric acid that is produced, five tons

59 of PG are generated (Zairi \& Rouis, 1999; Tayibi et al., 2009). This waste product is well known

60 to contain several types of pollutants such as heavy metals, fluorine, phosphorus and even

61 radioactive isotopes (Rutherford, Dudas \& Samek, 1994; Zairi \& Rouis, 1999; Pérez-López,

62 Alvarez-Valero \& Nieto, 2007; Ajam et al., 2009; El Afifi et al., 2009; Tayibi et al., 2009; Ajmal

63 et al., 2014). Phosphogypsum is generally stored on land forming giant stacks (up to $60 \mathrm{~m}$ high)

64 but at Gabes, all the industrial waste (including PG, industrial sludge, and wastewater) is directly

65 discharged into the sea.

66 This industrial pollution has heavily contaminated the marine sediments (El Zrelli et al., 2015;

67 Gargouri et al., 2011; Wali et al., 2013; Ayadi, Aloulou \& Bouzid 2015; Mkawar et al., 2007)

68 and seawater (Darmoul, Hadj-Ali \& Vitiello, 1980; El Zrelli et al., 2018). Resultant heavy metal

69 bioaccumulation in marine fauna is documented (Rabaoui et al., 2014; Messaoudi et al., 2009). 
70 The decline of the coral Cladocora caespitosa in the region (El Kateb et al., 2016) and of

71 macrobenthic faunas (Zaouali, 1993; Pérez Domingo, Castellanos \& Junoy, 2008; El Lakhrach et

72 al., 2012) can be also attributed to the pollution.

73 Aside from impacting the phosphorus and heavy metal contents in the sediments and water,

74 additional forms of pollution are generated by the phosphate industry including increased

75 siltation of the seafloor. At the beginning of the $20^{\text {th }}$ century, a large part the Gulf of Gabes was

76 colonized by the seagrass Posidonia oceanica (El Zrelli et al., 2017 and references therein). Ben

77 Brahim et al. (2010) estimated a $90 \%$ loss of this seagrass cover since 1960, which has

78 consequently caused prominent siltation. A large area of the Gulf is today covered by silty and

79 muddy sediments (El Kateb et al., 2018b).

80 During the last decades benthic foraminifera have been widely used to investigate environmental

81 conditions (e.g., Resig, 1960; Watkins, 1961), and their application has been recently extended to

82 assess the ecological status (e.g., Murray, 2006; Martínez-Colón, Hallock \& Green-Ruíz, 2009;

83 Hallock et al., 2003; Hallock, 2012; Schönfeld et al., 2012; Dimiza et al. 2016; and Martínez-

84 Colón et al., 2018, and references therein). Compared to other macro-and micro-organisms,

85 benthic foraminifera are advantageous because (i) they occur in marine environments all over the

86 world; (ii) a small volume of sediment sample is needed to use them in environmental

87 assessments due to the high foraminiferal densities (up to thousand specimens per $100 \mathrm{~cm}^{3}$ of

88 sediment) and (iii) their short life cycle allows them to rapidly react to external stressors, e.g.

89 pollutant contamination, anomalously high organic matter supply (eutrophication/nutrification)

90 (e.g., Schönfeld et al., 2012; Alve et al., 2016; Jorissen et al., 2018, and reference therein) and/or

91 thermal stress. Their added value is also the production of a mineralized test that is preserved in 
92 the sedimentary archives which provides the possibility to reconstruct paleoenvironmental and

93 paleoclimatic changes.

94 Numerous studies, based on living foraminifera, are used to highlight faunal changes as a

95 response to short-term stresses (e.g., Morvan et al., 2004; Denoyelle et al., 2010). These

96 investigations require the living cell to be stained at the time of sampling. The FOBIMO

97 Initiative was instigated to meet the requirements of the Marine Strategy Framework Directive-

98 MSFD (European Parliament, MSFD, 2008/56/EC). It provided, for the first time, a standardized

99 protocol for sampling and treating sediments for biomonitoring studies based on living (stained)

100 benthic foraminifera (Schönfeld et al., 2012). This protocol is presently accepted and applied to

101 assess the impacts of pollution on marine environments (e.g., Buosi et al., 2013; Titelboim et al.,

102 2016) it has therefore, been applied in this study.

103 Only a few studies, based on benthic foraminifera, have been conducted in the Gulf of Gabes.

104 The investigation of Aloulou, EllEuch \& Kallel (2012) along the northern coast of the Gulf and

105 of Ayadi et al. (2016) in the proximity of the industries at Gabes are based on total benthic

106 foraminiferal assemblages. As these two studies use total assemblages they cannot be considered

107 as representative of the current ecological and environmental conditions. An additional study on

108 living benthic foraminifera in Tunisia from Martins et al. $(2015,2016 a)$ concerns the Bizerta

109 lagoon, a site with a very limited access to the open Mediterranean, located in northern Tunisia,

110 far from the influence of the Gabes industries.

111 The aim of the present research is to document variations in benthic foraminiferal assemblage

112 composition in relation to the pollution sources, to assess the response of living (stained) benthic

113 foraminifera to the pollution produced by the phosphate industries in the Gulf of Gabes and to

114 provide a comparison with a more pristine site (Djerba Island). 
116 MATERIALS AND METHODS

\section{Study area}

118 The investigated area is located in the Gulf of Gabes, a 90km wide and $100 \mathrm{~km}$ long embayment

119 in the Mediterranean Sea. It is delimited by the Kerkhenna Islands to the north and Djerba Island

120 to the south. Its bathymetry is gently sloping from the coast to around $150 \mathrm{~km}$ with a $\pm 50 \mathrm{~m}$

121 water depth. Within this region, tides are the highest of the entire Mediterranean Sea reaching 1.7

$122 \mathrm{~m}$ (Aloulou, EllEuch \& Kallel, 2012). The thirty-eight investigated stations can be subdivided

123 into three groups (Fig. 1, Table 1): Gabes (16 stations, from GBS-01 to GBS-16) and Djerba

124 transects (15 stations, from DJB-01 to DJB-15); Coastal stations (7 stations, from CST-01 to

125 CST-07).

126

\section{Sampling and Samples Treatment}

128 The Djerba and Gabes transects were sampled in July 2014, perpendicular to the coastline at

129 water depths ranging from 4.5 to $19.5 \mathrm{~m}$ and 5.1 to $26.8 \mathrm{~m}$, respectively. The Gabes transect

130 (GBS-01 to GBS-16) is $17.3 \mathrm{~km}$ long and is located between the industrial and fishing harbours

131 of Gabes. Stations are positioned at approximately $1 \mathrm{~km}$ intervals. The Djerba transect (DJB-01

132 to DJB-15) is $13.8 \mathrm{~km}$ long and is located off the eastern coast of Djerba Island (El Kateb et al.,

133 2018b). Similarly, stations are positioned approximately $1 \mathrm{~km}$ apart. Five sedimentary facies

134 were identified along the Gabest transect (FG1-FG5) and three along the Djerba trasect (FD1-

135 FD3, Fig. 2, Table 2).

136 Coastal stations (CST-01 to CST-07) were collected in January 2014, along the shoreline at

137 shallow depths $(<1 \mathrm{~m})$ and cover $200 \mathrm{~km}$ of the eastern Tunisian coastline. One station is located 
138 in the Gulf of Hammamet next to El Kantaoui harbour (CST-01), four stations are located along

139 the Gulf of Gabes from Skhira to Zarat (CST-02 to CST-05) and two stations are located along

140 the western coast of Djerba Island (CST-06 and CST-07) (El Kateb et al, 2018b).

141 Sediment samples from both the Gabes and Djerba transects were collected using an Ekman-

142 Birge box corer $(15 \times 15 \times 30 \mathrm{~cm})$, which was deployed from a small fishing boat. Sediments

143 from coastal stations were collected by hand. All samples were collected and treated following

144 the FOBIMO protocol (Schönfeld et al., 2012). The first centimeter of surface sediment (an area

145 of $\left.50 \mathrm{~cm}^{2}\right)$ was collected in plastic bottles and placed in a rose Bengal solution $(2 \mathrm{~g} / \mathrm{L}$ in alcohol

146 at $90 \%$ ) for several weeks. The living (stained) foraminifera were investigated with a Nikon

147 SMZ18 microscope, picked and placed in plummer cells, identified at species level and counted.

148 Taxonomic identifications at species level follows Cimerman \& Langer (1991), Hottinger,

149 Halicz \& Reiss (1993), Loeblich \& Tappan (1994), Milker \& Schmiedl (2012) (Supplementary

150 Material 1).

151

152 Geochemical analyses

153 The phosphorus sequential extraction (SEDEX) method of Ruttenberg et al. (2009) was applied

154 to all samples. The SEDEX extraction allows an accurate quantification of the different

155 sedimentary phosphorus reservoirs in both modern sediments and sedimentary rocks

156 (Ruttenberg, 1992; Coletti et al., 2017). The Total Organic Carbon (TOC in wt \%) was measured

157 with Rock-Eval6 (Behar, Beaumont \& Penteado, 2001). Total carbon, hydrogen and nitrogen (C,

$158 \mathrm{H}, \mathrm{N}$ ) content (in wt \%) were measured in all surface sediment samples using a Thermo Finnigan

159 Flash EA 1112 gas chromatography analyser. Seawater samples were collected at the seafloor;

160 elemental analyses (e.g., As, Cd, Cu, Ni, Fe, Cr, Li, Pb, Zn, P) were carried out by inductively 
161 coupled plasma optical emission spectroscopy (ICP-OES). More detailed descriptions of all the

162 geochemical methods can be found in El Kateb (2018), El Kateb et al., (2018b), El Kateb et al.

163 (in press), raw data are here presented in Supplementary Material 2.

164

165 Statistical Treatment

166 Quantitative foraminiferal counts were treated with the Primer 7 software (Clarke et al., 2014).

167 The data set was fourth root transformed to limit the contribution of the most abundant species

168 (Field et al., 1982) and the Bray-Curtis (dis-)similarity calculated. A Similarity Profile

169 (SIMPROF) cluster analysis was performed to objectively define the groups within the

170 dendrogram(Fig. 3) and Multidimensional Scaling (MDS) plots (Fig. 4). Based on the SIMPROF

171 grouping, a Similarity Percentage (SIMPER) analysis was run to identify discriminating taxa

172 both within and between the groups. To assess the relationship between the biotic (foraminiferal)

173 assemblage data and measured environmental (sediment and water) parameters a BIOENV and

174 global BEST test (statistical significance) were performed. Following this, and using the

175 identified best combination of environmental parameters, a LINKTREE analysis (Fig. 5) was

176 performed to link the foraminiferal assemblage patterns with the suite of environmental

177 parameters.

178

179 RESULTS

180 Six thousand, eight hundred and eighty seven living (stained) benthic foraminiferal specimens,

181 belonging to 161 species, were identified (Supplementary material 2 and 3).

182 Samples collected close to the industry in Gabes (GBS-01 to 02) are dominated by Ammonia

183 tepida and Ammonia parkinsoniana with rare specimens of Brizalina striatula, the number of 
184 species at these stations varies from 5 to 8 and the correspondent Shannon Index is around 1.5.

185 Sample GBS-03, collected in the industrial sludge, is barren of benthic foraminifera. The other

186 samples collected along the Gabes transect (GBS-04 to -15) contain a variable number of species

187 from 6 (in GBS-09) to 37 (in GBS-10 and -11), with a Shannon Index of 0.8 and 2.6,

188 respectively. In these samples the assemblages mostly consist of $A$. tepida, Asterigerinata

189 mamilla, B. striatula, Bulimina alazanensis, Bulimina elegantisima, Eggerelloides scaber.

190 Samples collected along the Djerba transect (DJB-01 to -15) generally consist of Amphistegina

191 lessonii, Gavelinopsis praegeri, Neoconorbina terquemi, Peneroplis spp. Planorbulina

192 mediterranensis, varying in abundance from sample to sample. The number of species varies

193 from 15 to 48 and Shannon Index ranges from 2.2 to 3.0.

194 Assemblage composition, documented in coastal stations, is very variable. Station CST-04 is

195 barren of benthic foraminifera, whereas stations CST-06 and -07 contain the dominant Ammonia

196 beccarii, and abundant A. parkinsoniana and Quinqueloculina laevigata. All other species

197 (Supplementary Material 1) are rarer. The species number varies from 12 to 25 and the Shannon

198 Index from 2.2 to 2.3. The more representative species identified in the Gulf of Gabes are

199 documented in Figs. 6 to 11.

200 The SIMPROF Cluster analysis identified 6 clusters/groups within the Gabes and Djerba

201 samples. All coastal stations including the foraminifera-barren coastal (CST-04) and Gabes

202 sample (GBS-03) grouped separately (Figs. 2-3).

203 This outlier group was not used for additional statistical analyses because samples were either

204 not analysed for the geochemical characterization (e.g., coastal stations) or were barren of

205 benthic foraminifera (GBS-03 and CTS-04) or, in the case of all the CST, samples were collected 
206 in a different season (January: winter). Thus, assemblages that are linked to seasonality cannot be

207 compared to those from the Gabes and Djerba transects collected in July (summer) 2014.

208 Cluster A include only the sample GBS-06. This sample separates from Cluster B (samples

209 GBS-07 to -08 and GBS-10 to -16) only because of the abundant presence of Textularia conica

210 (66 specimens) that is otherwise rare (Table 3, Supplementary material 1).

211 Cluster B is characterized by the highest contributions from E. scaber, B.elegantissima and B.

212 striatula (Table 3). Bulimina marginata has a lower, yet similarly consistent contribution to the 213 group.

214 Cluster C groups samples GBS-04 and -05 and has dominant contributions from Trochammina 215 inflata and Rosalina villardeboana and lesser contributions by Q. laevigata, Textularia conica, 216 B. striatula, B. elegantissima and Cornuspira involvens (Table 3).

217 Cluster D groups samples DJB-01 and -12 that are characterized by A. lessonii and to a lesser 218 extent by $R$. villardeboana and P. mediterranensis (Table 3).

219 Cluster E groups all the other samples from the Djerba transect (DJB-02 to -11, and DJB-13 to 220 15) that are predominantly characterized by Rosalina macropora and $R$. villardeboana and to a 221 lesser extent by B. striatula, A. lessonii, A. mamilla and Peneroplis pertusus (Table 3).

222 Cluster F groups samples GBS-01 to -02 and GBS-09. These are characterized by A. tepida and 223 B. striatula (Table 3).

224

225 DISCUSSION

226 Environmental conditions in the study area

227 The adverse environmental conditions in the Gulf of Gabes are well documented (e.g., El Zrelli 228 at al., 2015, 2017; El Kateb et al., 2016, 2018b and references therein). The research of El Zrelli 
229 et al. (2017) highlighted that the order of heavy metal concentrations in sediments follows

$230 \mathrm{Zn}>\mathrm{Cd}>\mathrm{Cr}>\mathrm{Pb}>\mathrm{Cu}>\mathrm{Hg}$ and that at least $\mathrm{Zn}$ and $\mathrm{Cd}$ derive from phosphogypsum. These authors

231 observed that concentrations are higher close to the industrial complex and decrease toward the

232 open sea. El Kateb (2018) and El Kateb et al (in press) report high heavy metals (Zn, Cd, As, Cr,

$233 \mathrm{Fe}, \mathrm{Cu}$ ) and phosphorus concentrations in the sea water as well as elevated Ptot and TOC in

234 sediment samples collected close to the industrial complex at Gabes. The concentrations of the

235 measured elements is higher along the Gabes transect than along the Djerba transect, with the

236 exception of $\mathrm{Zn}$. In particular, $\mathrm{Zn}$ concentrations in the sea water, along the Gabes transect

237 (ranging between $7.05 \mathrm{ppm}$ at GBS-11 and $64.63 \mathrm{ppm}$ at GBS-16), are not as high as those

238 reported by El Zrelli et al. (2017) in their coastal stations sediments (ranging from 5.2 ppm along

239 the coast to $7165 \mathrm{ppm}$ in front of the industrial complex). On the contrary it is relatively

240 abundant in samples from the Djerba transect with a maximum of $104.75 \mathrm{ppm}$ at DJB-15. El

241 Kateb et al. (in press) propose that the low concentrations at Gabes could be related to the

242 precipitation of $\mathrm{Zn}$ from the water into sphalerite (El Kateb et al., 2018b) and the subsequent

243 transport of part of the remaining $\mathrm{Zn}$ off-shore during low tides (Othmani et al., 2017), while the

244 high concentrations at Djerba could be related to the decay of plankton, which releases dissolved

$245 \mathrm{Zn}$ into the seawater (Moore and Ramamoorthy, 1984).

246 Based on the BIOENV and global BEST test, 5 of the measured environmental variables,

247 cadmium (Cd), arsenic (As), phosphorus (P), total organic carbon (TOC) and total phosphorus

248 (Ptot), were found to be best indices to separate (statistically significant at $p<0.001$ ) the biotic

249 (foraminiferal) assemblage data $(\rho=0.764)$. The LINKTREE plot (Fig. 5) shows that all the

250 GBS samples cluster out from the DJB samples. The former all have elevated values in both the

251 measured water (Cd, As, P) and sediment (TOC and Ptot) parameters. 


\section{Living foraminifera assemblages and their significance}

254 Cluster A and B: Polluted Environment. These two clusters can be considered together as the

255 only difference between the two is the abundant $T$. conica in Cluster A (which is composed by

256 only one sample, GBS-06) and a different substratum (Fig. 3), Facies G3 for GBS-06, and Facies

257 G4 for all stations of Cluster B. These two clusters group the majority of the stations in the Gulf

258 of Gabes (Figs. 2-3).

259 The dominant foraminiferal species is E. scaber (Table 3). Murray (2006) described this species

260 as infaunal, detritivore and typical of shelf environments. Bouchet (2007) suggests that the

261 sedimentary detrital organic matter represents the main food resource for this species. Dessandier

262 et al. (2016) studied the distribution of E. scaber along the Portuguese coast, highlighting its

263 preference for environments characterized by high-quality of the organic matter (e.g., high

264 chlorophyll-a to phaeopigment ratio and available amino acids). Murray (2013) reported that $E$.

265 scaber is sensitive to salinity not exceeding $24 \mathrm{psu}$ and oxygen depletion $(<0.5 \mathrm{ml} / \mathrm{L})$, and that it

266 is tolerant to fluctuations in temperature and heavy metal pollution. Other highly contributing

267 species toof Cluster A and B are B. elegantissima and B. striatula, two stress-tolerant species

268 able to survive in polluted environmental conditions and under oxygen depletion (e.g., Murray,

269 2006; Dimiza et al., 2019, and references therein). Martins et al., (2016a) documented the

270 preference of $B$. striatula for high quality organic matter enriched in proteins, carbohydrates and

271 chlorophyll -a.

272 In general, taxa which are tolerant to such conditions are typically associated with muddy

273 substrates that can accumulate high amounts of organic matter (e.g., Van der Zwaan et al., 1999

274 and reference therein). This is evident as Cluster B includes stations from Facies G4 (clay with 
275 centimetric biogenic fragments). For Cluster B, the SIMPER analysis additionally identified the

276 stress-tolerant species A. tepida and B. marginata (e.g., Dimiza et al., 2019; Jorisse et al., 2018),

277 as well as Haynesina depressula, and Nonionoides grateloupi, which are classified as

278 "indifferent species" by Jorissen et al. (2018). The relatively high contribution of A. mamilla in

279 Cluster B (Table 3) in addition to its high abundances in samples from Clusters A and B

280 (Supplementary Material 1) is not consistent with its life strategy from the literature. Murray

281 (2013) described this species as epifaunal clinging on large detrital fragments or on marine

282 vegetation. Dimiza et al. (2016) show the negative correlation between abundances of $A$. mamilla

283 and the percent of mud. Is the quality of the organic matter playing a role on the abundance of

284 this species? The abundance of this species may be, indeed, linked to the high quality of the

285 organic matter, whose $\delta^{13} \mathrm{C}$ signature corresponds to marine phytoplankton, along the Gabes

286 transect (Supplementary Material 2; El Kateb et al., 2018b, El Kateb et al., in press).

287 Alternatively, the centimetric bioclasts characterizing Facies G4 may provide a suitable

288 ecological niche for A. mamilla (Fig. 3, Table 2).

289 The LINKTREE (Fig. 5) shows that stations grouped in Cluster A and B separates based on the

290 relatively high (in relation the Djerba samples) values of TOC (=<3.34 wt. \%), As $(=<1.26$

$291 \mu \mathrm{g} / \mathrm{L}), \mathrm{Cd}(0.73-1.19 \mu \mathrm{g} / \mathrm{L})$ and phosphorus both in the sediments $(87.1>$ Ptot $>28.7 \mu \mathrm{mol} / \mathrm{g})$ and

292 sea water $(\mathrm{P}>144 \mu \mathrm{g} / \mathrm{L})$.

293 In conclusion, the living (stained) benthic foraminifera assemblages from Clusters A and B are

294 interpreted to reflect high sedimentary organic matter supply, in a stressed environment due to

295 heavy metals and phosphorus contamination deriving from the Gabes industry. 296 
298 contributors of this cluster (exceeding 13\%) are T. inflata and R. vilardeboana (Table 3). It

299 groups only two stations (GBS-04 and -05) which are characterized by sandy carbonate

300 sediments and large biogenic fragments (Facies G3 in Table 2, El Kateb et al., 2018b) that may

301 represent an ideal habitat for $R$. villardeboana. This species is described as stress-tolerant in

302 culturing experiments (Hintz et al., 2004) and has been reported living in shallow water (Erginal

303 et al., 2013), similarly to station GBS-04, with a water depth not exceeding $12 \mathrm{~m}$ (El Kateb et al.,

304 2018b). Trochammina inflata is a species known to be highly tolerant to physicochemical

305 variability (Murray, 2006; Martins et al. 2016b). It is a cosmopolitan epifaunal or infaunal,

306 euryhaline marsh species, living down to $60 \mathrm{~m}$ of water depth and with a general preference for

307 muddy substrates (Usera et al., 2002; Murray, 2016; Benito et al., 2016). The abundance of $T$.

308 inflata within these samples may be due to the physicochemical variability linked to the tides

309 that in this region reach the highest variations (up to $2 \mathrm{~m}$, Aloulou, EllEuch \& Kallel, 2012).

310 Other species of this cluster are the stress-tolerant B. striatula, B. elegantissima and C. involvens,

311 attributed to group 3 third-order opportunists, tolerant to and favoured by the first stages of

312 organic enrichment (Alve et al., 2016; Jorissen et al., 2018). Rare specimens of Q. laevigata and

313 T. conica (not exceeding 3 and 13 specimens, respectively) also occur, these species are

314 considered as "sensitive" by Jorissen et al. (2018).

315 Cluster $\mathrm{C}$ is characterized by low species and low specimen numbers. In the LINKTREE (Fig.

316 5) it groups with Cluster A and B with relatively high TOC (=<3.34 wt. \%), As (=<1.26 $\mu \mathrm{g} / \mathrm{L})$,

$317 \mathrm{Cd}(0.73-1.19 \mu \mathrm{g} / \mathrm{L})$ and high phosphorus concentrations both in the sediments $(87.1<$ Ptot $>28.7$

$318 \mu \mathrm{mol} / \mathrm{g}$ ) and the sea water $(\mathrm{P}>144 \mu \mathrm{g} / \mathrm{L})$. In summary, the living (stained) benthic foraminifera

319 assemblages from Cluster $\mathrm{C}$ represent a stressed environment under the impact of heavy metal 
320 and phosphorus contamination deriving from the Gabes industry. This is in combination with

321 unstable physicochemical conditions that may account for the presence of more sensitive species.

322

323 Cluster D and E: Seagrass meadows and "pristine" sites". These clusters group all stations from 324 the Djerba transect (Figs. 2-3). The living (stained) foraminifera assemblages of Clusters D and 325 E show significant differences in comparison to the other clusters (Fig. 3 Table 3), highlighted 326 by the consistent presence of sensitive species such as A. lessonii. Amphisteginids are large 327 symbiont-bearing foraminifera widely used as bioindicators to assess water quality due to their

328 fast response to environmental changes, e.g. water temperature and photo-oxidation (e.g.,

329 Emrich, Martínez-Colón \& Alegria, 2017; De Freitas Prazeres, Martins \& Bianchini, 2012;

330 Hallock et al. 2006; Spezzaferri et al., 2018). Water transparency is an essential factor for 331 Amphistegina spp. because these organisms host symbionts and, as such, are light dependent

332 (Hallock, 1981). El Kateb et al. (2018c) suggest that the presence of $P$. oceanica meadows along

333 the Djerba transect promotes the development of A. lessonii. This species is also very sensitive to

334 heavy metal pollution because these pollutants directly affect its symbiotic algae. Furthermore,

335 De Freitas Prazeres, Martins \& Bianchini (2011) demonstrated, in culture, that zinc exposure

336 causes visual alteration such as bleaching and/or dark brown areas in the test.

337 Cluster D is characterized by $A$. lessonii and to a lesser extent by $R$. villardeboana, $P$.

338 mediterranensis and R. macropora and includes two samples DJB-01 collected in the $P$.

339 oceanica meadow (Facies D1) and DJB-12 (Facies D3, well-preserved biogenic fragments of

340 bivalves, calcareous algae, gastropods and bryozoans), characterized by abundant degraded

341 algae. $R$. vilardeboana is especially abundant at station DJB-01, where $P$. oceanica traps the

342 sediments in its rhizomes to form small barriers. Planorbulina mediterranensis is epifaunal 
343 clinging on hard substrata and/or seagrass (Villanueva Guimerans \& Cervera Currado, 1999).

344 Mateu-Vicens et al. (2010) mentioned high abundances of this species in P. oceanica meadows,

345 which is corroborated at station DJB-01 where the seagrass is densely covering the sea floor (El

346 Kateb et al., 2018b). As an epifauna foraminifera, R. macropora is generally associated with

347 sandy and vegetated substrate (Vidović et al., 2014 and references therein). Elshanawany et al.

348 (2011) proposed R. macropora to be a species relatively sensitive to pollution.

349 Cluster E is characterized primarily by $R$. macropora, $R$. villardeboana in addition to the species

350 B. striatula, A. lessonii, A. mamilla, P. pertusus. It includes all the remaining samples from

351 Djerba covering a variety of Facies, from D1 to D3, ranging from $P$. oceanica meadows to fine

352 sediment with biogenic clasts of various sizes. Similarly to the epibenthic and sensitive $A$.

353 lessonii, P. pertusus is also a symbiont-bearing species and needs high light intensities (Samir \&

354 El Din, 2001 and references therein). Amao, Kaminski \& Setoyama (2016) suggested that this

355 species is associated with the presence of marine flora. There are no investigations showing the

356 pollution impact on this species but as a symbiont-bearing foraminifera, it can be considered as

357 sensitive to anthropogenic-related stressors such as heavy metals. Within this cluster the

358 occurrence of $A$. mamilla, $R$. vilardeboana and $R$. macropora seems to be linked to $P$. oceanica

359 meadows, which provides them with an ideal substratum. Brizalina striatula is an infaunal

360 species relatively tolerant to oxygen depletion and feeding on organic detritus (e.g., Murray,

361 2006). El Kateb et al. (2018a) documented abundant B. striatula linked to $P$. oceanica meadows,

362 indicating that the remains of $P$. oceanica may represent a potential food resource for this

363 species.

364 All the Djerba sites are characterized by the highest species numbers, specimen numbers and

365 Shannon diversities (Supplementary Material 1). They separate in the LINKTREE (Fig. 5) based 
366 on the lowest values of $\mathrm{P}$, Ptot and $\mathrm{Cd}(<17.6 \mu \mathrm{g} / \mathrm{L},<0.62 \mu \mathrm{mol} / \mathrm{g}$ and $23.5 \mu \mathrm{g} / \mathrm{L}$, respectively)

367 confirming the more negative association of the species, identified in the SIMPER analysis for

368 Clusters D and E, with lower levels of pollution.

369 In summary, benthic foraminifera of Cluster D and E seem to be linked to $P$. oceanica meadows.

370 Sensitive species such as $A$. lessonii and peneroplidae suggest relatively "pristine" environments

371 where anthropogenic stress is minor (Triantaphyllou et al., 2005; Koukousioura et al., 2012).

372

373 Cluster F: Major industrial impact. This cluster groups Sample GBS-01, -02 and -09. The first

374 two samples are located in front of the industrial complex at Gabes and are the closest to the

375 pollution source, whereas sample GBS-09 is located further away. Sample GBS-02 was collected

376 in the industrial sludge consisting of dark siliciclastic sediments (Facies G1, Fig. 3, Table 3),

377 where concentrations of TOC and heavy metals reach the highest values in both seawater and

378 marine sediments (Supplementary Material 2; El Zrelli et al., 2015, 2018; Ayadi, Aloulou \&

379 Bouzid, 2015; El Kateb et al., 2018b). Major contributors to this cluster are A. tepida and B.

380 striatula, two stress-tolerant species. In particular, A. tepida is well known to tolerate pollution

381 and elevated concentrations of TOC (e.g., Samir \& El-Din, 2001; Armynot du Châtelet \&

382 Debenay 2004; Dimiza et al., 2019). This cluster is characterized by the lowest species numbers,

383 specimen numbers and Shannon diversities (Supplementary Material 1). The grouping of Sample

384 GBS-09 with -01 and -02 is possibly due to the fine nature of the sediments that favors the

385 accumulation of organic matter resulting in high TOC concentrations (Facies G5, Table 3, Figs.

386 3, 5) (e.g., Tyson, 1995; Bergamaschi et al., 1997). . Samples GBS-02 and -01 are still

387 distinguished by their strong relation to high concentrations of Ptot, As and Cd ( $>282 \mu \mathrm{mol} / \mathrm{g}$,

$388>2.9 \mu \mathrm{g} / \mathrm{L}$ and $2.61 \mu \mathrm{g} / \mathrm{L}$, respectively) 
389 The living benthic foraminifera of Cluster F can be interpreted as stess-tolerant assemblage

390 linked to in response to high pollution levels (P, As, Cd) in a eutrophic setting.

391

392 Validation of Results

393 El Kateb et al. (2018b) documented, in the target region, different environmental conditions

394 characterized by differing geochemical parameters such as TOC, phosphorous content and grain

395 size. Nevertheless, some dominant foraminiferal species are present over a large part of the

396 studied area and are common in the Mediterranean Sea, both in the open sea and lagoons

397 (Martins et al., 2015; 2016a) and, therefore, it is difficult to assign a specific environmental

398 preference to them (e.g., A. mamilla, B. striatula). However, the distribution and abundance of

399 the most representative species, illustrated in plots (Fig. 4) clearly shows that the clusters are

400 related to their ecological preferences. For example the stress-tolerant species E. scaber, $B$.

401 elegantissima, B. striatula, B. marginata, A. tepida are primarily abundant in the same clusters

402 (Cluster A, B, C and F) which corresponds to the GBS samples. On the contrary, epibenthic

403 species, such as $A$. lessonii, $R$. macropora, $R$. vilardeboana and peneroplids are also most

404 abundant in Clusters D and E. The consistent species distributions and clustering of stations,

405 according to their foraminiferal content and geochemical/facies characterization (Figs. 2, 5),

406 confirms that the interpretation of species ecological preferences is plausible. It also highlights

407 that species distributions are linked both to pollution and substratum type (Basso \& Spezzaferri, 408 2000).

409

410

411

412

Peer) reviewing PDF | (2019:09:41510:1:1:NEW 29 Jan 2020) 


\section{CONCLUSION}

414 The Gulf of Gabes, in the Lesser Syrtis (Tunisia), is presently characterized by intense pollution

415 from the phosphate treatment industries. This quantitative investigation on benthic foraminiferal

416 assemblages has revealed the presence of five clusters representing: polluted settings (Clusters A

417 and B); polluted environments characterized by physicochemical variability (Cluster C), seagrass

418 meadows and "pristine" sites (Cluster D and E) and the area characterized by the major industrial

419 impact (Cluster F).

420 The major pollutants in this region are phosphorus, organic matter, and the heavy metals, in

421 particular As and $\mathrm{Cd}$, affecting benthic foraminiferal assemblages at various degrees. Eighteen

422 species are dominant but only ten show high statistical contributions to the clusters. The most

423 stress-tolerant species are Ammonia tepida (Cluster F) accompanied by E. scaber, B.

424 elegantissima, B. striatula (Cluster A and B). Trochamina inflata may be interpreted as an

425 indicator of physiochemical variability in the environment (Cluster C). Amphistegina spp.,

426 peneroplidae, $P$. mediterranensis, $R$. macropora and $R$. villardeboana can be considered as

427 sensitive species living in $P$. oceanica meadows or clinging on coarse substratum (Clusters D

428 and $\mathrm{E})$.

429

430 ACKNOWLEDGMENTS

431 We are especially grateful to Kamel El Kateb for the organization of the field assessment in the

432 Gulf of Gabes and to Christoph Neururer for his help during the sampling. This work was funded

433 by the Swiss National Science Foundation through grant 200021_149589.

434

435

Peer] reviewing PDF | (2019:09:41510:1:1:NEW 29 Jan 2020) 


\section{REFERENCES}

439

440 Ajam L, Ouezdou MB, Felfoul HS, El Mensi R. 2009. Characterization of the Tunisian

441 phosphogypsum and its valorization in clay bricks. Construction and Building Materials 23(10):

$442 \quad 3240-3247$.

443

444

Ajmal PY, Bhangare RC, Tiwari M, Sahu SK, Pandit GG. 2014. External gamma radiation levels and natural radioactivity in soil around a phosphate fertilizer plant at Mumbai. Journal of

446 Radioanalytical and Nuclear Chemistry 300(1): 23-27.

447

448 Aloulou F, EllEuch B, Kallel M. 2012. Benthic foraminiferal assemblages as pollution proxies in

449 the northern coast of Gabes Gulf, Tunisia. Environmental monitoring and assessment 184(2): $450 \quad 777-795$.

451

452 Alve E, Korsun S, Schönfeld J, Dijkstra N, Golikova E, Hess S, Husum K, Panieri G. 2016.

453 Foram-AMBI: A sensitivity index based on benthic foraminiferal faunas from North-East

454 Atlantic and Arctic fjords, continental shelves and slopes. Marine Micropaleontology 122: 1-12. 455

456 Amao AO, Kaminski MA, Setoyama E. 2016. Diversity of Foraminifera in a shallow restricted 457 lagoon in Bahrain. Micropalaeontology 62 :197-211. 
459 Ayadi N, Aloulou F, Bouzid J. 2015. Assessment of contaminated sediment by phosphate

460 fertilizer industrial waste using pollution indices and statistical techniques in the Gulf of Gabes

461 (Tunisia). Arabian Journal of Geosciences 8(3): 1755-1767.

462

463 Ayadi N, Zghal I, Aloulou F, Bouzid J. 2016. Impacts of several pollutants on the distribution of 464 recent benthic foraminifera: the southern coast of Gulf of Gabes, Tunisia. Environmental Science 465 and Pollution Research 23(7): 6414-6429.

466

467 Basso D, Spezzaferri S. 2000. The distribution of living (stained) benthic foraminifera in 468 Iskenderun Bay (Eastern Turkey): a statistical approach. Bolletino-Societa Paleontologia Italiana 469 39(3): 359-380.

470

471 Behar F, Beaumont V, Penteado HL De B. 2001. Rock-Eval 6 Technology: Performances and 472 Developments. Oil \& Gas Science and Technology`Revue d'IFP Energies nouvelles. 56(2): 111473134.

474

475 Ben Brahim MB, Hamza A, Hannachi I, Rebai A, Jarboui O, Bouain A, Aleya L. 2010.

476 Variability in the structure of epiphytic assemblages of Posidonia oceanica in relation to human 477 interferences in the Gulf of Gabes, Tunisia. Marine Environmental Research 70(5): 411-421. 478

479 Bouchet VMP. 2007. Dynamique et réponse fonctionnelle des foraminifères et de la macrofaune 480 benthique en zone ostreicole dans les pertuis charentais. PhD thesis, Angers, France. 
482 Buosi C, Cherchi A, Ibba A, Marras B, Marrucci A, Schintu M. 2013. Preliminary data on

483 benthic foraminiferal assemblages and sedimentological characterisation from some polluted and 484 unpolluted coastal areas of Sardinia (Italy). Bollettino della Società Paleontologica Italiana 485 52(1): 35-44.

486

487 Cimerman F, Langer MR. 1991. Mediterranean Foraminifera Slovenska Akademija Znanosti in 488 Umetnosti. Academia Scientiarum et Artium Slovenica, Ljubljana.

489

490 Coletti G, El Kateb A, Basso D, Cavallo A, Spezzaferri S. 2017. Nutrient influence on fossil 491 carbonate factories: Evidence from SEDEX extractions on Burdigalian limestones (Miocene, 492 NW Italy and S France). Palaeogeography Palaeoclimatology Palaeoecology 475: 80-92. 493

494 Clarke KR, Gorley RN, Somerfield PJ, Warwick RM. 2014. Change in marine communities: an 495 approach to statistical analysis and interpretation, 3rd edition. PRIMER-E: Plymouth. 496

497 Darmoul B, Hadj-Ali M, Vitiello P. 1980. Effets des rejets industriels de la région de Gabès 498 (Tunisie) sur le milieu marin récepteur. Bulletin de l'Institut national scientifique et technique 499 d'océanographie et de pêche Salammbô 7: 5-61.

500

501 Denoyelle M, Jorissen FJ, Martin D, Galgani F, Miné J. 2010. Comparison of benthic

502 foraminifera and macrofaunal indicators of the impact of oil-based drill mud disposal. Marine 503 Pollution Bulletin 60(11): 2007-2021. 
505 Dessandier P-A, Bonnin J, Kim J-H, Bichon S, Deflandre B, Grémare A., Sinninghe Damsté JS.

506 2016. Impact of organic matter source and quality on living benthic foraminiferal distribution on

507 a river-dominated continental margin: A study of the Portuguese margin, Journal of Geophysical

508 Research: Biogeoscience 121: 1689-1714. doi:10.1002/2015JG003231.

510 Dimiza MD, Triantaphyllou MV, Koukousioura O, Hallock P, Simboura N, Karageorgis AP,

511 Papathanasiou E. 2016. The Foram Stress Index: A new tool for environmental assessment of

512 soft-bottom environments using benthic foraminifera. A case study from the Saronikos Gulf,

513 Greece, Eastern Mediterranean. Ecological indicators 60: 611-621.

515 Dimiza MD, Ravani A, Kapsimalis V, Panagiotopoulos IP, Skampa E, Triantaphyllou MV

516 2019. Benthic foraminiferal assemblages in the severely polluted coastal environment of

517 Drapetsona-Keratsini, Saronikos Gulf (Greece). Revue de Micropaléontologie 62: 33-44

518

519 De Freitas Prazeres M, Martins SE, Bianchini A. 2011. Biomarkers response to zinc exposure in

520 the symbiont-bearing foraminifer Amphistegina lessonii (Amphisteginidae, Foraminifera).

521 Journal of experimental marine biology and ecology 407(1): 116-121.

523 De Freitas Prazeres M, Martins SE, Bianchini A. 2012. Assessment of water quality in coastal

524 waters of Fernando de Noronha, Brazil: biomarker analyses in Amphistegina lessonii. The

525 Journal of Foraminiferal Research 42(1): 56-65.

526 
527 El Afifi EM, Hilal MA, Attallah MF, El-Reefy SA. 2009. Characterization of phosphogypsum

528 wastes associated with phosphoric acid and fertilizers production. Journal of Environmental

529 Radioactivity 100(5): 407-412.

530

531 El Kateb A, Stalder C, Neururer C, Pisapia C, Spezzaferri S. 2016. Correlation between pollution 532 and decline of Scleractinian Cladocora caespitosa (Linnaeus, 1758) in the Gulf of Gabes.

533 Heliyon 2(11): e00195.

535 El Kateb A, Stalder C, Neururer C, Fentimen R, Spangenberg JE, Spezzaferri S. 2018a.

536 Distribution of benthic foraminiferal assemblages in the transitional environment of the Djerba

537 lagoon (Tunisia). Swiss Journal of Geosciences 111: 589-606. https://doi.org/10.1007/s00015$538 \quad 018-0300-0$

540 El Kateb A, Stalder C, Rüggeberg A, Neururer C, Spangenberg JE, Spezzaferri S. 2018b. Impact

541 of industrial phosphate waste discharge on the marine environment in the Gulf of Gabes

542 (Tunisia). PloS ONE 13(5): e0197731.

544 El Kateb A, Stalder C, Stainbank S, Fentimen R, Spezzaferri S. 2018c. The genus Amphistegina 545 (benthic foraminifera): distribution along the southern Tunisian coast. BioInvasion Records 7(4): $546 \quad 391-398$.

547

548 El Kateb A, Stalder C, Martinez-Colon M, Mateu-Vicens G, Francescangeli F, Coletti G,

549 Stainbank S, Spezzaferri S. in press. Foraminiferal-based biotic indices to assess ecological 
550 quality status of the Gulf of Gabes (Tunisia): present limitations and future perspectives.

551 Ecological Indicators. 111, 105962, doi: /10.1016/j.ecolind.2019.105962.

552

553 El Lakhrach H, Hattour A, Jarboui O, El Hasni K, Ramos-Esplá AA. 2012. Spatial distribution 554 and abundance of the megabenthic fauna community in Gabes Gulf (Tunisia, eastern

555 Mediterranean Sea). Mediterranean Marine Science 13(1): 12-29.

556

557 El Zrelli R, Courjault-Radé P, Rabaoui L, Castet S, Michel S, Bejaoui N. 2015. Heavy metal

558 contamination and ecological risk assessment in the surface sediments of the coastal area

559 surrounding the industrial complex of Gabes city, Gulf of Gabes, SE Tunisia. Marine pollution

560 bulletin 101(2): 922-929.

561

562 El Zrelli R, Courjault-Radé P, Rabaoui L, Daghbouj N, Mansour L, Balti R, Castet S, Attia F,

563 Michel S, Bejaoui N. 2017. Biomonitoring of coastal pollution in the Gulf of Gabes (SE,

564 Tunisia): use of Posidonia oceanica seagrass as a bioindicator and its mat as an archive of

565 coastal metallic contamination. Environmental Science and Pollution Research 24(28): 22214-

56622225.

567

568

El Zrelli R, Rabaoui L, Alaya MB, Daghbouj N, Castet S, Besson P, Michel S, Bejaoui N,

569 Courjault-Radé P. 2018. Seawater quality assessment and identification of pollution sources

570 along the central coastal area of Gabes Gulf (SE Tunisia): Evidence of industrial impact and

571 implications for marine environment protection. Marine Pollution Bulletin 127: 445-452. 
573 Elshanawany R, Ibrahim MI, Milker Y, Schmiedl G, Badr N, Kholeif SE, Zonneveld KA. 2011.

574 Anthropogenic impact on benthic foraminifera, Abu-Qir Bay, Alexandria, Egypt. The Journal of

575 Foraminiferal Research 41(4): 326-348.

576

577 Emrich K, Martínez-Colón M, Alegria H. 2017. Is untreated seawage impacting coral reefs of 578 Caye Caulker, Belize? Journal of Foraminiferal Research 47(1): 20-33.

579

580 Erginal AE, Ekinci YL, Demirci A, Bozcu M, Ozturk MZ, Avcioglu M, Oztura E. 2013. First

581 record of beachrock on Black Sea coast of Turkey: Implications for Late Holocene sea-level

582 fluctuations. Sedimentary Geology 294: 294-302.

583

584 European Parliament, 2008. Directive 2008/56/ec of the European Parliament and of the Council 585 of 17 June 2008 , establishing a framework for community action in the field of marine

586 environmental policy (Marine Strategy Framework Directive). Official Journal of the European 587 Union L 164/19 (http://eur-lex.europa.eu).

588

589 Gargouri D, Azri C, Serbaji MM, Jedoui Y, Montacer M. 2011. Heavy metal concentrations in 590 the surface marine sediments of Sfax Coast, Tunisia. Environmental monitoring and assessment 591 175(1-4): 519-530.

592

593 Hallock P. 1981. Light dependence in Amphistegina. The Journal of Foraminiferal Research 594 11(1): 40-46. 
596 Hallock P. 2012. The FoRAM Index revisited: uses, challenges, and limitations. Proceedings of 597 the $12^{\text {th }}$ International Coral Reef Symposium, Cairns, Australia, 9-13.

598

599 Hallock P, Lidz BH, Cockey-Burkhard EM, Donnelly KB. 2003. Foraminifera as bioindicators

600 in coral reef assessment and monitoring: the FORAM index. Environmental monitoring and 601 assessment 81(1-3): 221-238.

602

603 Hallock P, Williams DE, Fisher EM, Toler SK. 2006. Bleaching in foraminifera with algal 604 symbionts: implications for reef monitoring and risk assessment: Anuario do Instituto de 605 Geociencias, Universidade Federal do Rio de Janeiro, Brasil 29: 108-128.

606

607 Hintz CJ, Chandler GT, Bernhard JM, McCorkle DC, Havach SM, Blanks JK, Shaw TJ. 2004. A 608 physicochemically constrained seawater culturing system for production of benthic foraminifera. 609 Limnology and Oceanography, Methods 2(6): 160-170.

610

611 Hottinger L, Halicz E, Reiss Z. 1993. Recent foraminiferida from the Gulf of Aqaba, Red Sea.

612 Academia Scientiarum et Artium Slovenica, Classis IV: Historia Naturalis, 33, Lubljana. 613

614 Jorissen FJ, Nardelli MP, Almogi-Labin A, Barras C, Bergamin L, Bicchi E, El Kateb A, Ferraro 615 L, McGann M, Morigi C, Romano E, Sabbatini A, Schweizer M, Spezzaferri S. 2018.

616 Developing Foram-AMBI for biomonitoring in the Mediterranean: Species assignments to 617 ecological categories. Marine Micropaleontology 140: 33-45. 
619 Koukousioura O, Triantaphyllou MV, Dimiza MD, Pavlopoulos K, Syrides G, Vouvalidis K.

620 2012. Benthic foraminiferal evidence and paleoenvironmental evolution of Holocene coastal

621 plains in the Aegean Sea (Greece). Quaternary International 261: 105-117.

622

623 Loeblich ARJr, Tappan H. 1994. Foraminifera of the Sahul Shelf and Timor Sea. Special

624 Publication of the Cushman Foundation for Foraminiferal Research Special Publication 31: 1625661.

626

627 Mateu-Vicens G, Box A, Deudero S, Rodríguez B. 2010. Comparative analysis of epiphytic

628 foraminifera in sediments colonized by seagrass Posidonia oceanica and invasive macroalgae

629 Caulerpa spp. The Journal of Foraminiferal Research 40(2): 134-147.

630

631 Martínez-Colón M, Hallock P, Green-Ruíz CR. 2009. Strategies for using shallow-water benthic

632 foraminifers as bioindicators of potentially toxic elements: a review. The Journal of

633 Foraminiferal Research 39(4): 278-299.

634

635 Martínez-Colón M, Hallock P, Green-Ruíz CR, Smoak JM. 2018. Benthic foraminifera as

636 bioindicators of potentially toxic element (PTE) pollution: Torrecillas lagoon (San Juan Bay

637 Estuary), Puerto Rico. Ecological Indicators 89: 516-527.

638

639 Martins MVA, Zaaboub N, Aleya L, Frontalini F, Pereira E, Miranda P, Mane M, Rocha F, Laut

640 L, El Bour M. 2015. Environmental quality assessment of Bizerte Lagoon (Tunisia) using living 
641 foraminifera assemblages and a multiproxy approach. PLoS ONE 10(9): e0137250.

642 https://doi.org/10.1371/journal.pone.0137250

643

644 Martins MVA, Helali MA, Zaaboub N, Boukef-BenOmrane I, Frontalini F, Reis D, Portela H,

645 Matos Morea Clemente IA, Nogueira L, Pereiro E, Miranda P, El Bour M, Aleya L. 2016a.

646 Organic matter quantity and quality, metals availability and foraminifera assemblages as

647 environmental proxy applied to the Bizerte Lagoon (Tunisia). Marine Pollution Bulletin 105:

648 161-179.

649

650 Martins MVA, Fernandez Sousa Pinto A, Frontalini F. MArchado de Fonseca MC, Lara Terroso

651 D. Matos Laut, LL, Zaaboub N, da Conceiç ao Rodrigues A, Rocha A. 2016b. Can benthic

652 foraminifera be used as bio-indicators of pollution in areas with a wide range of physicochemical 653 variability? Estuarine, Coastal and Shelf Science 182: 211-225.

654

655 Messaoudi I, Deli T, Kessabi K, Barhoumi S, Kerkeni A, Saïd K. 2009. Association of spinal

656 deformities with heavy metal bioaccumulation in natural populations of grass goby,

657 Zosterisessor ophiocephalus Pallas, 1811 from the Gulf of Gabès (Tunisia). Environmental

658 monitoring and assessment 156(1-4): 551-560.

659

660 Milker Y, Schmiedl G. 2012. A taxonomic guide to modern benthic shelf foraminifera of the 661 western Mediterranean Sea. Palaeontologia electronica 15(2): 1-134.

662 
663 Mkawar S, Azri C, Kamoun F, Montacer M. 2007. Impact sur les biophases marines des rejets 664 anthropiques, notamment des métaux lourds rejetés sur le littoral nord de la ville de Sfax 665 (Tunisie). Techniques Sciences Méthodes 10: 71-85.

666

667 Moore, JR, Ramamoorthy SS. 1984. Heavy Metals in Natural Waters. Springer Verlag, New 668 York.

669

670 Morvan J, Le Cadre V, Jorissen F, Debenay JP. 2004. Foraminifera as potential bio-indicators of 671 the "Erika" oil spill in the Bay of Bourgneuf: Field and experimental studies. Aquatic living 672 resources 17(3): 317-322.

673

674 Murray JW. 2006. Ecology and applications of benthic foraminifera. Cambridge University 675 Press.

676

677 Murray JW. 2013. Living benthic foraminifera: biogeographical distributions and the 678 significance of rare morphospecies. Journal of Micropalaeontology 32(1): 1-58.

679

680 Othmani A, Béjaoui B, Chevalier C, Elhmaidi D, Devenon JL, Aleya L. 2017. High-resolution 681 numerical modelling of the barotropic tides in the Gulf of Gabes, eastern Mediterranean Sea 682 (Tunisia). Journal of African Earth Sciences 129: 224-232.

683

684 Pérez Domingo S, Castellanos C, Junoy J. 2008. The sandy beach macrofauna of Gulf of Gabes 685 (Tunisia). Marine Ecology 29(s1): 51-59. 
687 Pérez-López R, Alvarez-Valero AM, Nieto JM. 2007. Changes in mobility of toxic elements 688 during the production of phosphoric acid in the fertilizer industry of Huelva (SW Spain) and 689 environmental impact of phosphogypsum wastes. Journal of Hazardous Materials 148(3): 745690750.

691

692 Rabaoui L, Balti R, Zrelli R, Tlig-Zouari S. 2014. Assessment of heavy metals pollution in the 693 gulf of Gabes (Tunisia) using four mollusk species. Mediterranean Marine Science 15(1): 45-58. 694

695 Resig JM. 1960. Foraminiferal ecology around ocean outfalls off southern California. In:

696 Pearson EA. (Ed.) Waste Disposal in the Marine Environment. Pergamon Press, London, 104697121.

698

699 Ruttenberg KC. 1992. Development of a sequential extraction method for different form 700 of phosphorus in marine sediments. Limnology and Oceanography 37: 1460-1482.

701

702 Ruttenberg KC, Ogawa NO, Tamburini F, Briggs RA, Colasacco ND, Joyce E. 2009. Improved, 703 high through put approach for phosphorus speciation in natural sediments via the SEDEX

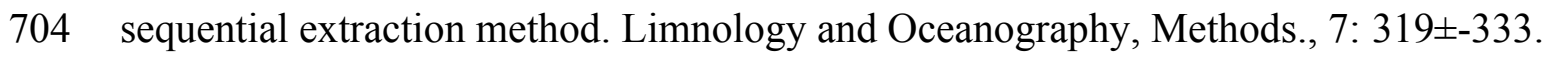
705

706 Rutherford PM, Dudas MJ, Samek RA. 1994. Environmental impacts of phosphogypsum.

707 Science of the total environment 149(1-2): 1-38. 
709 Samir AM, El-Din AB. 2001. Benthic foraminiferal assemblages and morphological

710 abnormalities as pollution proxies in two Egyptian bays. Marine Micropaleontology 41(3-4):

$711 \quad 193-227$.

712

713 Schönfeld J, Alve E, Geslin E, Jorissen F, Korsun S, Spezzaferri S. 2012. The FOBIMO

714 (FOraminiferal BIo-MOnitoring) initiative - Towards a standardised protocol for soft-bottom

715 benthic foraminiferal monitoring studies. Marine Micropaleontology 94: 1-13.

716

717 Spezzaferri S, El Kateb A, Pisapia C, Hallock P. 2018. In Situ Observations of Foraminiferal

718 Bleaching in the Maldives, Indian Ocean. Journal of Foraminiferal Research 48(1): 75-84.

719

720 Tayibi H, Choura M, López FA, Alguacil FJ, López-Delgado A. 2009. Environmental impact

721 and management of phosphogypsum. Journal of environmental management 90(8): 2377-2386. 722

723 Titelboim D, Almogi-Labin A, Herut B, Kucera M, Schmidt C, Hyams-Kaphzan O, Ovadia O, 724 Abramovich S. 2016. Selective responses of benthic foraminifera to thermal pollution. Marine 725 pollution bulletin 105(1): 324-336.

726

727 Triantaphyllou MV, Tsorout T, Koukousioura O, Dermi-Tzakis MD. 2005. Foraminiferal and 728 ostracod ecological patterns in the coastal environments of SE Andros Island (Middle Aegean

729 Sea, Greece). Revue de Micropaleontologie 48: 279-302.

730 
731 Tyson RV. 1995. Sedimentary organic matter. Organic facies and palynofacies. Chapman and

732 Hall, London, pp. 615.

733

734 Van der Zwaan GJ, Duijnstee IAP, Den Dulk M, Ernst SR, Jannink NT, Kouwenhoven TJ. 1999.

735 Benthic foraminifers: proxies or problems?: a review of paleocological concepts. Earth-Science

736 Reviews 46(1-4): 213-236.

737

738 Vidović J, Dolenec M, Dolenec T, Karamarko V, Rožǐc PŽ. 2014. Benthic foraminifera

739 assemblages as elemental pollution bioindicator in marine sediments around fish farm (Vrgada

740 Island, Central Adriatic, Croatia). Marine pollution bulletin 83(1): 198-213.

741

742 Villanueva Guimerans PV, Cervera Currado JC. 1999. Distribution of Planorbulinacea (benthic

743 foraminifera) assemblages in surface sediments on the northern margin of the Gulf of Cadiz.

744 Boletin-Instituto Espanol de Oceanografia 15(1-4): 181-190.

745

746 Wali A, Colinet G, Khadhraoui M, Ksibi M. 2013. Trace metals in surface soil contaminated by

747 release of phosphate industry in the surroundings of Sfax-Tunisia. Environmental Research,

748 Engineering and Management 65(3): 20-30.

749

750 Watkins JG. 1961. Foraminiferal ecology around the Orange County, California, ocean sewer

751 outfall. Micropaleontology 7: 199-206.

752 
753 Zairi M, Rouis MJ. 1999. Impacts environnementaux du stockage du phosphogypse à Sfax

754 (Tunisie). Bulletin-laboratoires des ponts et chaussées, 29-40.

755

756 Zaouali J. 1993. Les peuplements benthiques de la petite Syrte, golfe de Gabès-Tunisie.

757 Résultats de la campagne de prospection du mois de juillet 1990. Marine Life 3(1-2): 47-60.

758

759

760

761

762

763

764

765

766

767

768

769

770

771

FIGURE CAPTIONS

772

773 FIGURE 1. Location map. Location map of the Gulf of Gabes and position of the investigated

774 sites, showing the Gabes and Djerba transects and coastal stations (CST). Modified after El

775 Kateb et al. (2018b).

776 
777 FIGURE 2. Profiles of the Gabes and Djerba transects. Profiles of the Gabes and Djerba

778 transects showing the position of the collected samples, the sedimentary facies and the associated

779 SIMPROF Clusters (squares), modified after El Kateb et al. (2018b).

780

781 FIGURE 3. SIMPROF dendrogram and associated Clusters. SIMPROF dendrogram and

782 associated Clusters, based on the Bray-Curtis similarity matrix of fourth-root transformed living

783 (stained) benthic foraminifera abundance data from the Lesser Syrtis. Gray square indicates the

784 outlier Cluster composed of the foraminifera barren and all shallow coastal stations, note that

785 these are not considered in further statistical analyses.

786

787 FIGURE 4. nMDS plots showing SIMPROF clusters. nMDS plots showing SIMPROF

788 clusters and abundances of selected stress-tolerant benthic foraminferal species. Note that the

789 nMDS plot has no dimensions and no axes and can be arbitrarily scaled, located, rotated or

790 inverted. It gives simply the relationship of samples relative to each other (Clarke et al., 2014).

791

792 FIGURE 5. LINKTREE dendrogram. LINKTREE dendrogram showing the separation of

793 GBS and DJB samples according to the major pollutants.

794

795

FIGURE 6. Images of selected foraminifera species. A-B Ammoglobigerina glomigeriniformis

796

(Parker and Jones, 1865): A spiral view; B umbilical view. C-D Ammoscalaria runiuina (Heron-

797 Allen and Earland, 1916): C spiral view; D umbilical view. E-G Clavulina difformis (Brady,

798 1884): E, G side view; F top view. H-I Eggerelloides scaber (Williamson, 1858): side view. J-K

799 Glomospira charoides (Jones and Parker, 1860): side view. L-M Glomospira gordialis (Jones 
800 and Parker, 1860): L spiral view; M umbilical view. N-O Lagenammina fusiformis (Williamson,

801 1858): side view. P-Q Paratrochamina challengeri (Brönnimann and Whittaker, 1988): P spiral

802 view; Q umbilical view. R-S Paratrochammina madeirae (Brönnimann, 1979): R spiral view; S

803 umbilical view. T-U Trochammina inflata (Montagu, 1803): T spiral view; U umbilical view. V-

804 W Psammosphaera fusca (Schulze, 1825): V spiral view; W umbilical view. X-Y Textularia sp.:

805 side views. Z-AA Textularia conica (d'Orbigny, 1839): side views. BB-CC Textularia

806 pseudorugosa (Lacroix, 1932). DD-EE Textularia agglutinans (d'Orbigny, 1839): side views.

807 FF-HH Textularia calva (Lalicker, 1935): FF, HH side views; GG top view. II-JJ Mychostomina

808 revertens (Rhumbler, 1906): II spiral view; JJ umbilical view.

809

810 FIGURE 7. Images of selected foraminifera species. A-B Cornuspira involvens (Reuss, 1850):

811 side view. C-D Patellina corrugata (Williamson, 1858): C spiral view; D umbilical view. E-F

812 Vertebralina sp.: E spiral view; F umbilical view. G-H Wiesnerella auriculata (Egger, 1893): G

813 spiral view; H umbilical view. I-K Articulina carinata (Wiesner, 1923): I, K side view; J top

814 view. L-N Adelosina carinata-striata (Wiesner, 1923): L, M side view; N top view. O-Q

815 Adelosina cliarensis (Heron-Allen and Earland, 1930): O, Q side view; P top view. R-S

816 Adelosina laevigata (d'Orbigny, 1826) (juvenile): side views. T-U Affinetrina gualtieriana

817 (d'Orbigny, 1839): side views. V-X Cycloforina contorta (d'Orbigny, 1846) (with a broken

818 neck): V, W side view; X top view.; Y-AA Lachlanella variolata (d'Orbigny, 1826): Y, AA side

819 view; Z top view. BB-CC Pseudotriculina laevigata (d'Orbigny, 1826): side view. DD-EE

820 Quinqueloculina bidentata (d'Orbigny, 1839): side view. FF-GG Quinqueloculina bosciana

821 (d'Orbigny, 1839): side view. HH-JJ Quinqueloculina jugosa (Cushman, 1944): HH, JJ side

822 view; II top view.

Peer] reviewing PDF | (2019:09:41510:1:1:NEW 29 Jan 2020) 
823

824 FIGURE 8. Images of selected foraminifera species. A-C Quinqueloculina laevigata

825 (d'Orbigny, 1839): A, C side view; B top view. D-F Quinqueloculina pseudobuchiana

826 (Luczowska, 1974): D,F side view; E top view. G-H Quinqueloculina seminula (Lineaeus,

827 1758): side views. I-J Miliolinella subrotunda (Montagu, 1803): side views. K-M Miliolinella

828 webbiana (d'Orbigny, 1839): side views. N-O Biloculina (?) sp.: side views. P-Q

829 Laevipeneroplis karreri (Wiesner, 1923): P umbilical view; Q spiral view. R-T Peneroplis

830 planatus (Fichtel and Moll, 1798): R spiral view; S side view; T umbilical view. U-W Peneroplis

831 pertusus (Forskål, 1775): U, W spiral view; V side view. X-Y Sorites orbiculus (Ehrenberg,

832 1839): X spiral view; Y umbilical view. Z-AA Carterina spiculotesta (Carter, 1877): Z spiral

833 view; AA umbilical view. BB-CC Lagena striata (d'Orbigny, 1839) side view. DD-FF

834 Lenticulina cultrata (de Montfort, 1808): DD, FF spiral view; EE side view. GG-HH Bolivina

835 plicatella (Cushmann, 1930): side view. II-JJ Bolivina difformis (Williamson, 1858): side view.

836 KK-LL Brizalina striatula (Cushman, 1922): side view.

837

838 FIGURE 9. Images of selected foraminifera species. A-B Bulimininella elegantissima

839 (d'Orbigny, 1839): side view. C-D Bulimina elongata (d'Orbigny, 1846): side view. E-F

840 Bulimina marginata (d'Orbigny, 1826): side view. G-H Floresina sp.: side view. I-J Fursenkoina

841 acuta (d'Orbigny, 1846): side view. K-M Siphogenerina raphana (Parker and Jones, 1865): K, L

842 side view; M top view. N-O Sigmavirgulina tortuosa (Brady, 1881): side view. P-R

843 Abditodentrix rhomboidalis (Millet, 1899): P-Q side view; R top view. S-U Uvigerina sp.: S-T

844 side view; U top view. V-W Uvigerina canariensis (d'Orbigny): side view; X-Y Valvulineria

845 minuta (Parker, 1954): X umbilical view; Y spiral view. Z-AA Glabratella altispira (Buzas, 
846 Smith and Beem, 1977): Z spiral view; AA umbilical view. BB-CC Facetocochlea pulchra

847 (Cushman, 1933): BB spiral view; CC umbilical view. DD-EE Rosalina bradyi (Cushman,

848 1915): DD spiral view; EE umbilical view. FF-GG Rosalina globularis (d'Orbigny, 1826): FF

849 spiral view; GG umbilical view. HH-II Rosalina macropora (Hofker, 1951): HH spiral view; II

850 umbilical view. JJ-KK Rosalina pellucida (Said, 1949): JJ spiral view; KK umbilical view. LL-

851 MM Rosalina villardeboana (d'Orbigny, 1839): LL spiral view; MM umbilical view. NN-PP

852 Discorbinella concinna (Brady, 1884): specimen with floating chamber, NN spiral view; OO

853 side view, PP umbilical view.

854

855 FIGURE 10. Images of selected foraminifera species. A-B Rosalina bulloides (d'Orbigny,

856 1839): A spiral view; B umbilical view. C-D Cassidulina obtusa (Williamson, 1858): C spiral

857 view; D umbilical view. E-F Discorbinella berthelotti (d'Orbigny, 1839): E spiral view; F

858 umbilical view. G-H Cibicidella variabilis (d'Orbigny, 1826): G spiral view; H umbilical view.

859 I-J Gavelinopsis praegeri (Heron-Allen and Earland, 1913): I spiral view; J umbilical view. K-L

860 Neoconorbina terquemi (Rzehak, 1888): K spiral view; L umbilical view. M-N Planorbulina

861 mediterranensis (d'Orbigny, 1826): M spiral view; N umbilical view. O-P Planorbulina

862 mediterranensis (d'Orbigny, 1826): O spiral view; P umbilical view. Q-R Cymbaloporetta

863 bradyi (Cushman, 1915): Q spiral view; R umbilical view. S-U Asterigerinata mamilla

864 (Williamson, 1858): S spiral view; T side view; U umbilical view. V-X Astrononion stelligerum

865 (d'Orbigny, 1839): V, X spiral view; W side view. Y-Z Haynesina depressula (Walker and

866 Jacob, 1798): Y spiral view; Z umbilical view. AA-BB Haynesina simplex (Cushman, 1933): AA

867 spiral view; BB umbilical view. CC-DD Melonis affinis (Reuss, 1851): CC spiral view; DD

868 umbilical view. EE-FF Nonion fabum (Fichtel and Moll, 1798): EE spiral view; FF umbilical 
869 view. GG-HH Nonionella turgida (Williamson, 1858): GG spiral view; HH umbilical view. II-JJ

870 Noinionoides grateloupi (d'Orbigny, 1826): II spiral view; JJ umbilical view.

871

872 FIGURE 11. Images of selected foraminifera species. A-B Ammonia beccarii (Linnaeus, 873 1758): A spiral view; B umbilical view.; C-D Ammonia convexa (Collins, 1958): C spiral view;

874 D umbilical view. E-F Ammonia parkinsoniana (d'Orbigny, 1839): E spiral view; F umbilical

875 view. G-H Ammonia tepida (Cushman, 1926): G spiral view; H umbilical view. I-J Amphistegina 876 lessonii (d'Orbigny, 1826): I spiral view; J umbilical view. K-L Amphistegina lobifera (Larsen,

877 1976): K umbilical view; L spiral view. M-N Elphidium crispum (Linnaeus, 1758): spiral view.

878 O-P Elphidium depressulum (Cushman, 1933): spiral view. Q-R Elphidium incertum

879 (Williamson, 1858): spiral view.

880

881 TABLE CAPTIONS

882

883 TABLE 1. Coordinates. Geographic coordinates and water depths of the sampled stations.

884

885 TABLE 2. Facies. Summary of the identified sedimentary facies along the Gabes and Djerba

886 Transects (modified after El Kateb et al., 2018b).

887

888 TABLE 3. Statistical analyses. SIMPER analysis using the Bray-Curtis similarity matrix on

889 fourth-root transformed living (stained) benthic foraminifera abundance data from the Lesser

890 Syrtis. The main species contributing to the similarity within the SIMPROF cluster groups are

891 identified. Note: Only the taxa contributing $>5 \%$ to the within-group average similarity are 892 shown. 
893

894 SUPPLEMENTARY MATERIAL

895

896 SM1. Quantitative raw data of benthic foraminiferal assemblages. Quantitative raw data of

897 benthic foraminiferal assemblages, species number and Shannon (H'_log). Modified after El

898 Kateb et al. (2020).

899

900 SM2. Geochemical data. Geochemical data.

901

902 SM3. Taxonomy. Taxonomical list of benthic foraminifera identified in this study.

903 


\section{Figure 1}

\section{Location map}

Location map of the Gulf of Gabes and position of the investigated sites, showing the Gabes and Djerba transects and coastal stations (CST). Modified after El Kateb et al. (2018b).

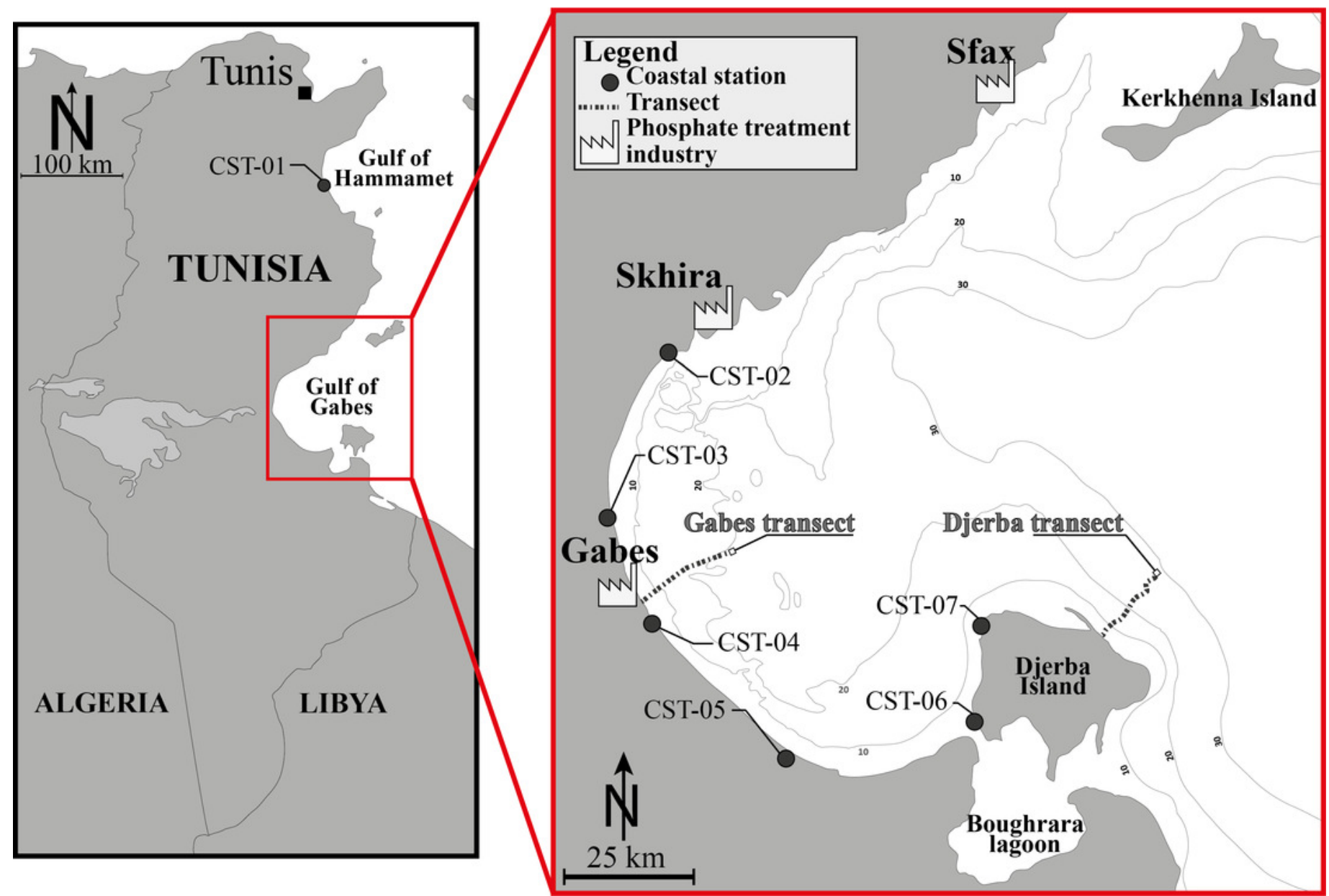


Figure 2

Profiles of the Gabes and Djerba transects.

FIGURE 2. Profiles of the Gabes and Djerba transects. Profiles of the Gabes and Djerba transects showing the position of the collected samples, the sedimentary facies and the associated SIMPROF Clusters (squares), modified after El Kateb et al. (2018b).
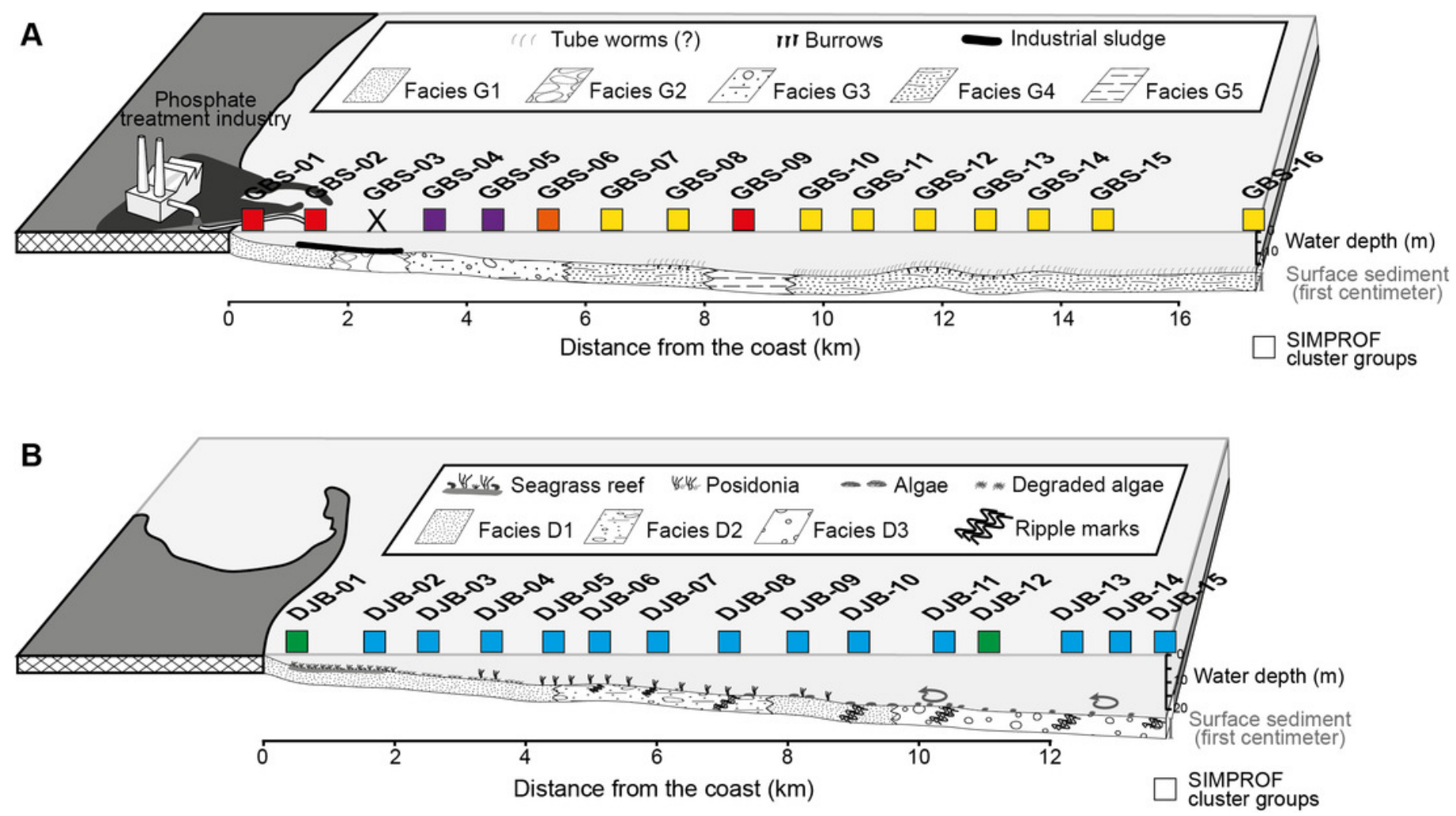
Figure 3

SIMPROF dendrogram and associated Clusters.

SIMPROF dendrogram and associated Clusters, based on the Bray-Curtis similarity matrix of fourth-root transformed living (stained) benthic foraminifera abundance data from the Lesser Syrtis. Gray square indicates the outlier Cluster composed of the foraminifera barren and all shallow coastal stations, note that these are not considered in further statistical analyses.

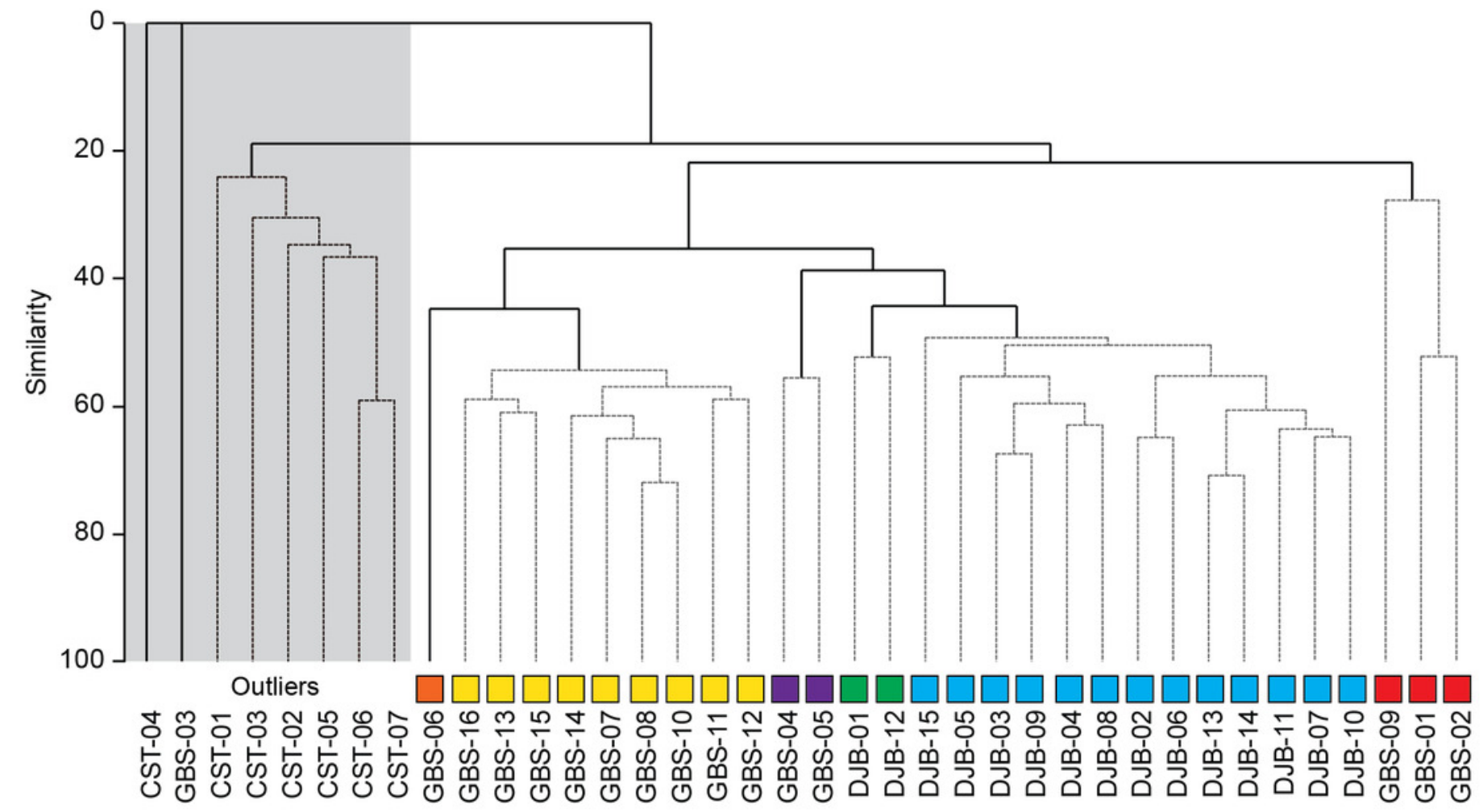

$\square$ Cluster A $\square$ Cluster B $\square$ Cluster C $\square$ Cluster D $\square$ Cluster E $\square$ Cluster F 


\section{Figure 4}

nMDS plots showing SIMPROF clusters.

nMDS plots showing SIMPROF clusters and abundances of selected stress-tolerant benthic foraminferal species. Note that the nMDS plot has no dimensions and no axes and can be arbitrarily scaled, located, rotated or inverted. It gives simply the relationship of samples relative to each other (Clarke et al., 2014). 


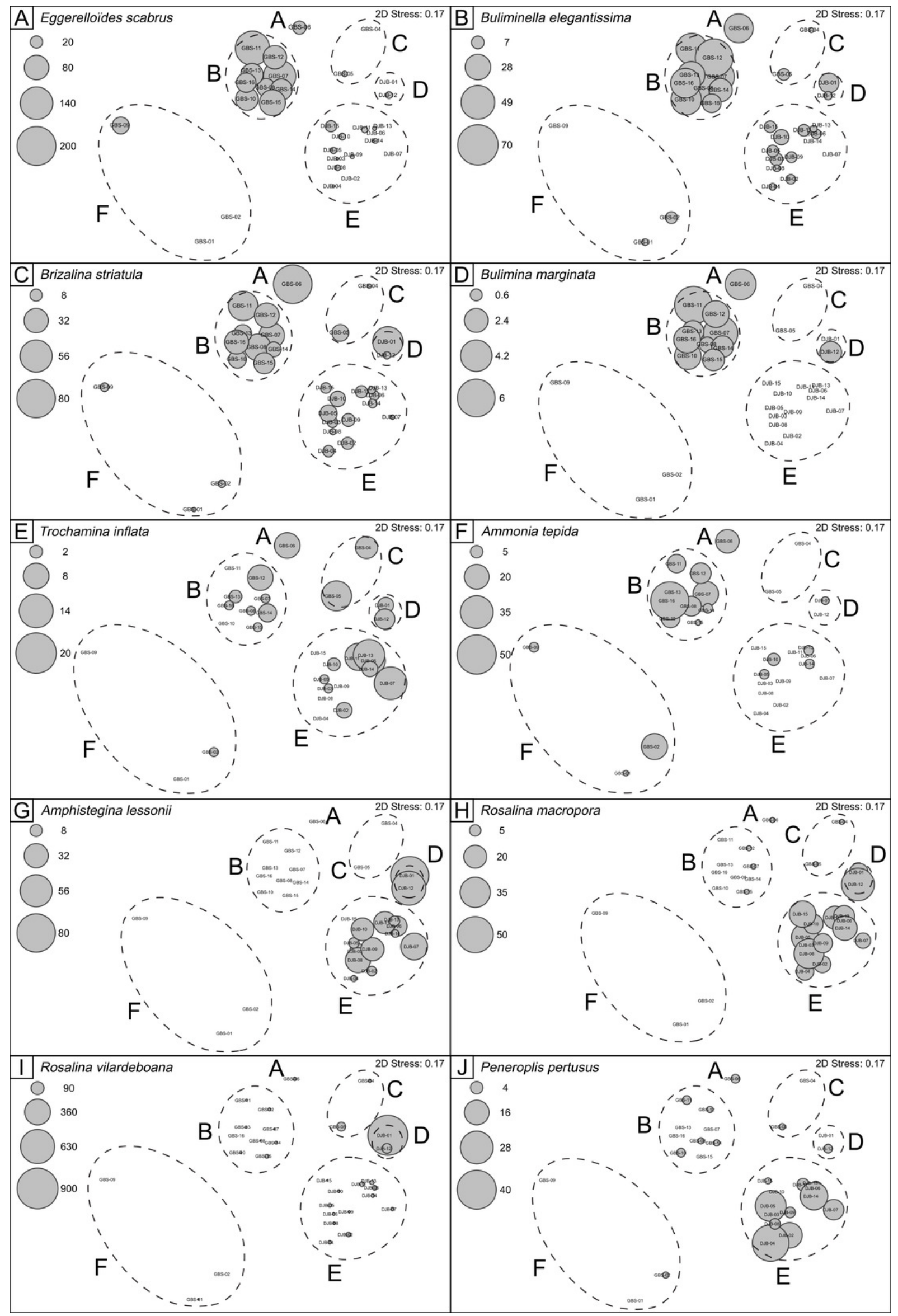


Figure 5

LINKTREE dendrogram.

LINKTREE dendrogram showing the separation of GBS and DJB samples according to the major pollutants.

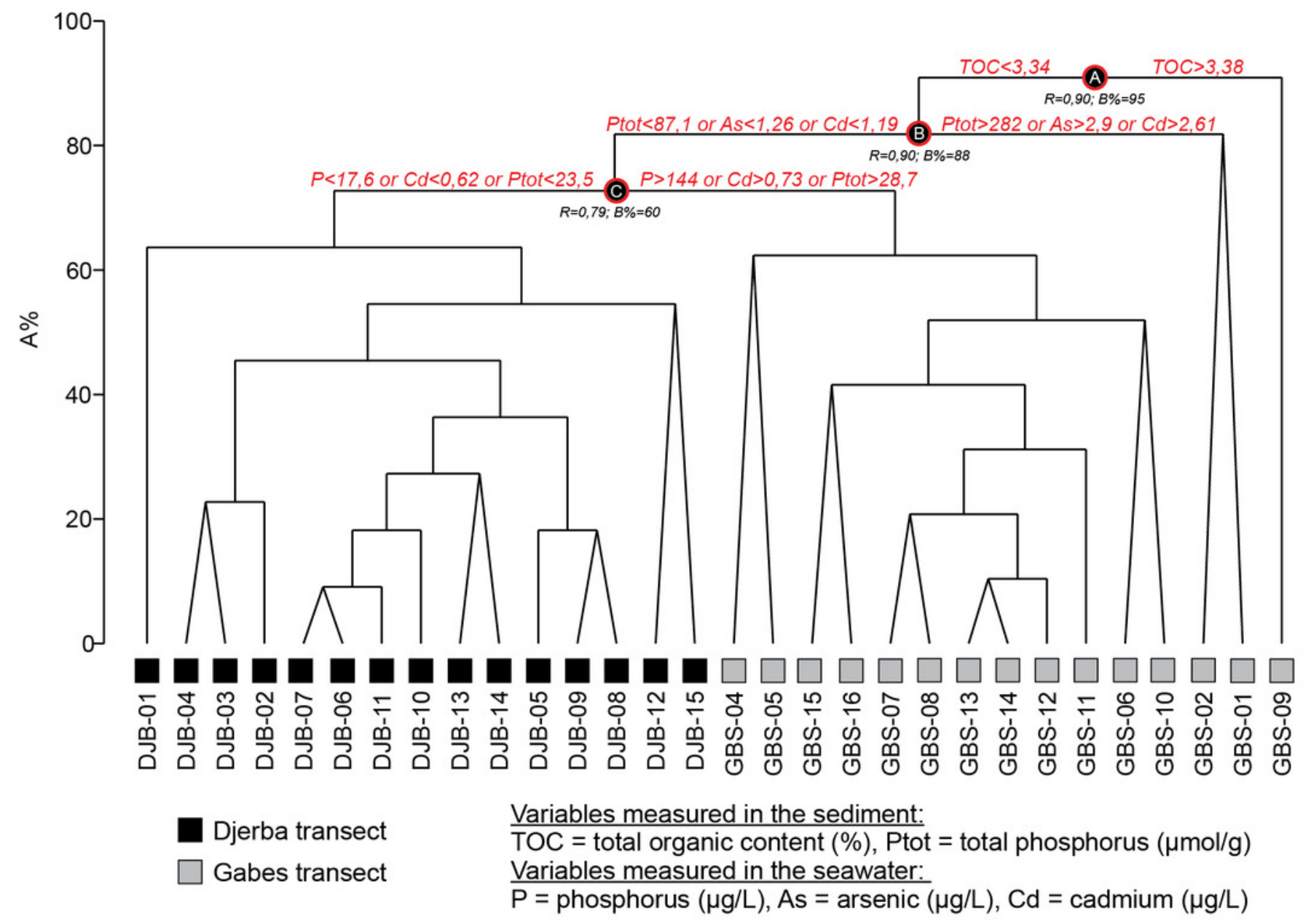




\section{Figure 6}

Images of selected foraminifera species.

A-B Ammoglobigerina glomigeriniformis (Parker and Jones, 1865): A spiral view; B umbilical view. C-D Ammoscalaria runiuina (Heron-Allen and Earland, 1916): C spiral view; D umbilical view. E-G Clavulina difformis (Brady, 1884): E, G side view; F top view. H-I Eggerelloides scaber (Williamson, 1858): side view. J-K Glomospira charoides (Jones and Parker, 1860): side view. L-M Glomospira gordialis (Jones and Parker, 1860): L spiral view; M umbilical view. N-O Lagenammina fusiformis (Williamson, 1858): side view. P-Q Paratrochamina challengeri (Brönnimann and Whittaker, 1988): P spiral view; Q umbilical view. R-S Paratrochammina madeirae (Brönnimann, 1979): R spiral view; S umbilical view. T-U Trochammina inflata (Montagu, 1803): T spiral view; U umbilical view. V-W Psammosphaera fusca (Schulze, 1825): V spiral view; W umbilical view. X-Y Textularia sp.: side views. Z-AA Textularia conica (d'Orbigny, 1839): side views. BB-CC Textularia pseudorugosa (Lacroix, 1932). DD-EE Textularia agglutinans (d'Orbigny, 1839): side views. FF-HH Textularia calva (Lalicker, 1935): FF, HH side views; GG top view. II-JJ Mychostomina revertens (Rhumbler, 1906): II spiral view; JJ umbilical view. 


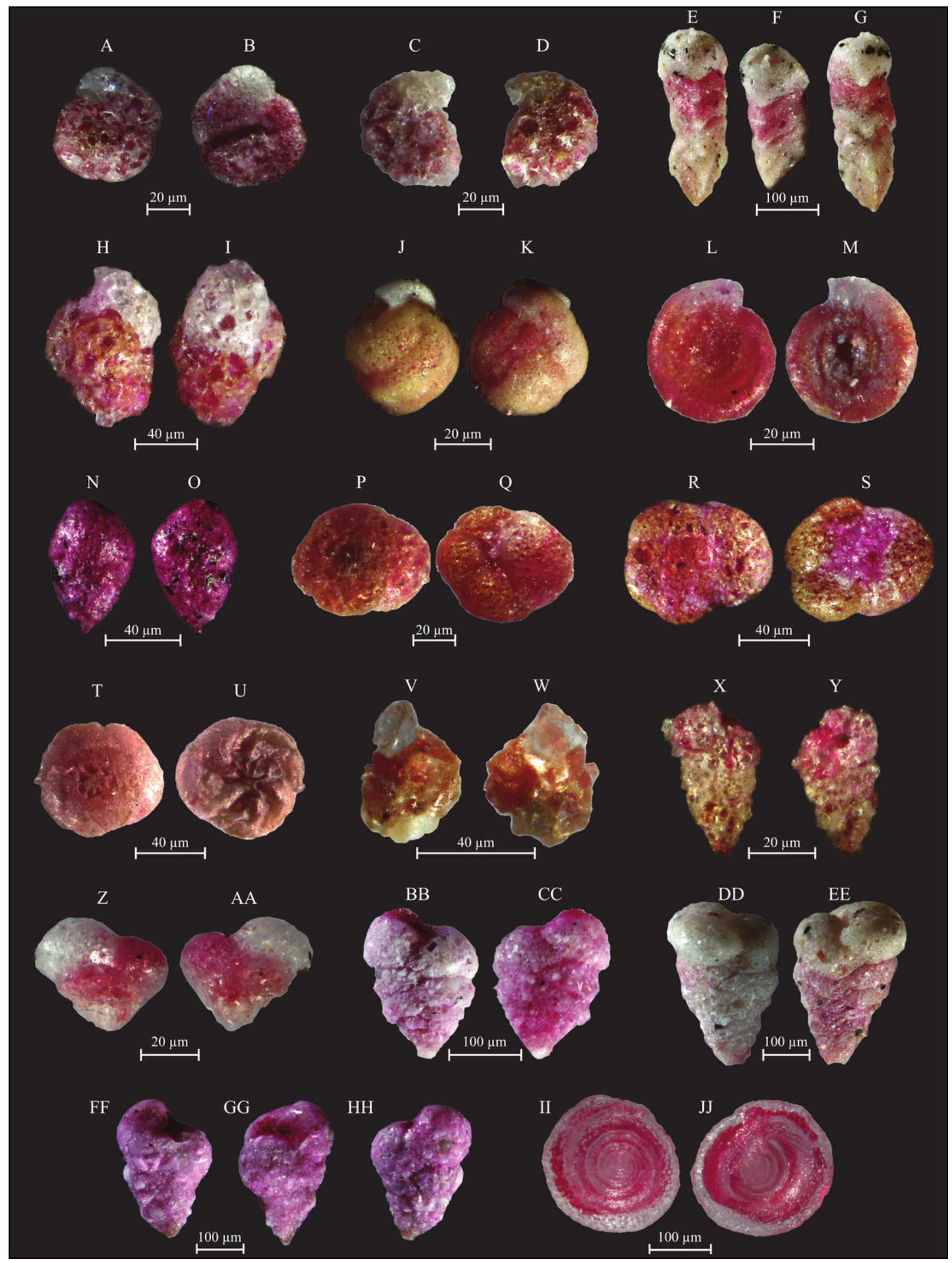




\section{Figure 7}

Images of selected foraminifera species.

A-B Cornuspira involvens (Reuss, 1850): side view. C-D Patellina corrugata (Williamson, 1858): C spiral view; D umbilical view. E-F Vertebralina sp.: E spiral view; F umbilical view. GH Wiesnerella auriculata (Egger, 1893): G spiral view; H umbilical view. I-K Articulina carinata (Wiesner, 1923): I, K side view; J top view. L-N Adelosina carinata-striata (Wiesner, 1923): L, M side view; N top view. O-Q Adelosina cliarensis (Heron-Allen and Earland, 1930): O, Q side view; P top view. R-S Adelosina laevigata (d'Orbigny, 1826) (juvenile): side views. T-U Affinetrina gualtieriana (d'Orbigny, 1839): side views. V-X Cycloforina contorta (d'Orbigny, 1846) (with a broken neck): V, W side view; $X$ top view.; Y-AA Lachlanella variolata (d'Orbigny, 1826): Y, AA side view; Z top view. BB-CC Pseudotriculina laevigata (d'Orbigny, 1826): side view. DD-EE Quinqueloculina bidentata (d'Orbigny, 1839): side view. FF-GG Quinqueloculina bosciana (d'Orbigny, 1839): side view. HH-JJ Quinqueloculina jugosa (Cushman, 1944): HH, JJ side view; II top view. 

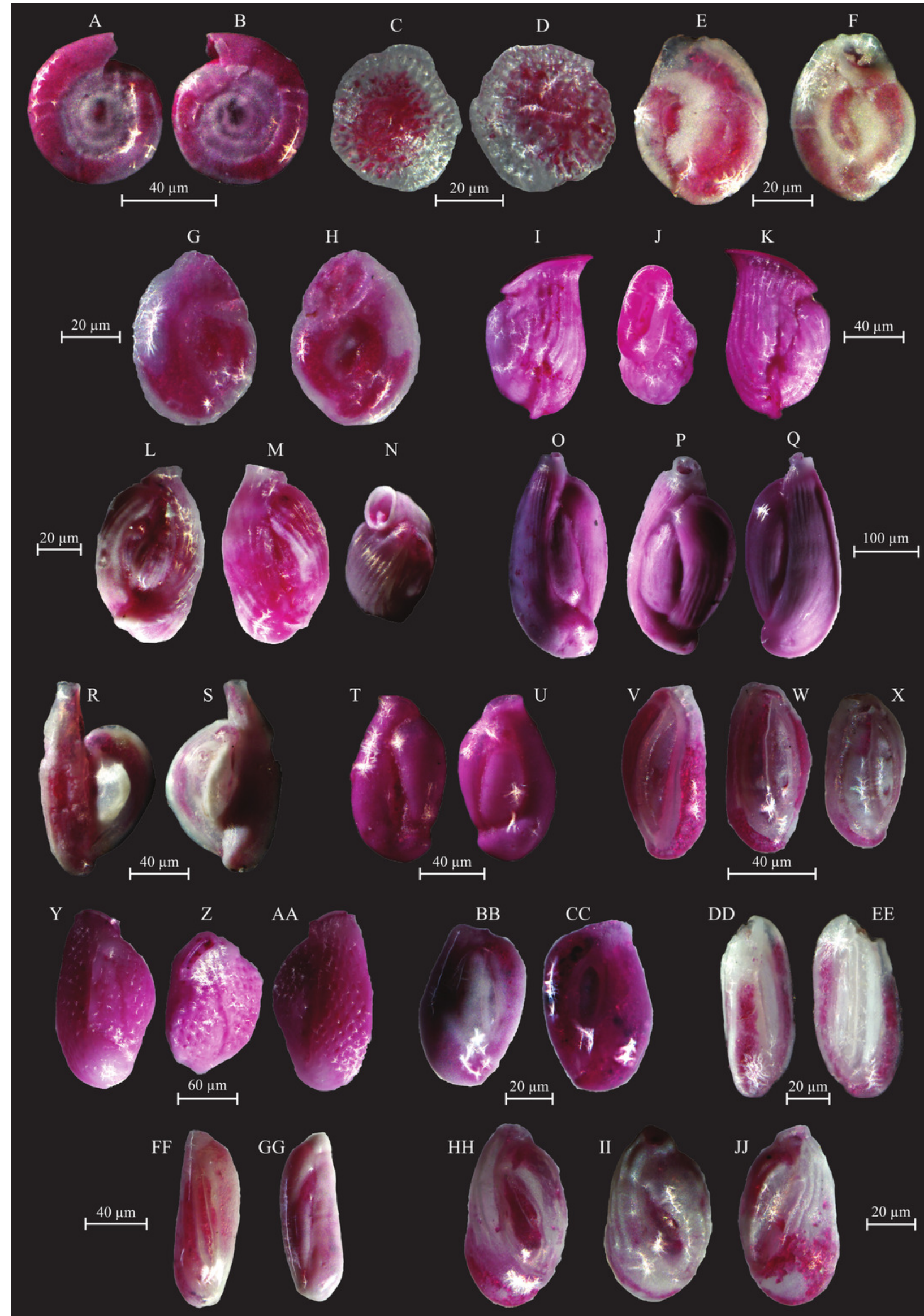


\section{Figure 8}

Images of selected foraminifera species.

A-C Quinqueloculina laevigata (d'Orbigny, 1839): A, C side view; B top view. D-F Quinqueloculina pseudobuchiana (Luczowska, 1974): D,F side view; E top view. G-H Quinqueloculina seminula (Lineaeus, 1758): side views. I-J Miliolinella subrotunda (Montagu, 1803): side views. K-M Miliolinella webbiana (d'Orbigny, 1839): side views. N-O Biloculina (?) sp.: side views. P-Q Laevipeneroplis karreri (Wiesner, 1923): P umbilical view; Q spiral view. R-T Peneroplis planatus (Fichtel and Moll, 1798): R spiral view; S side view; T umbilical view. U-W Peneroplis pertusus (Forskål, 1775): U, W spiral view; V side view. X-Y Sorites orbiculus (Ehrenberg, 1839): X spiral view; Y umbilical view. Z-AA Carterina spiculotesta (Carter, 1877): $Z$ spiral view; AA umbilical view. BB-CC Lagena striata (d'Orbigny, 1839) side view. DD-FF Lenticulina cultrata (de Montfort, 1808): DD, FF spiral view; EE side view. GG-HH Bolivina plicatella (Cushmann, 1930): side view. II-JJ Bolivina difformis (Williamson, 1858): side view. KK-LL Brizalina striatula (Cushman, 1922): side view. 


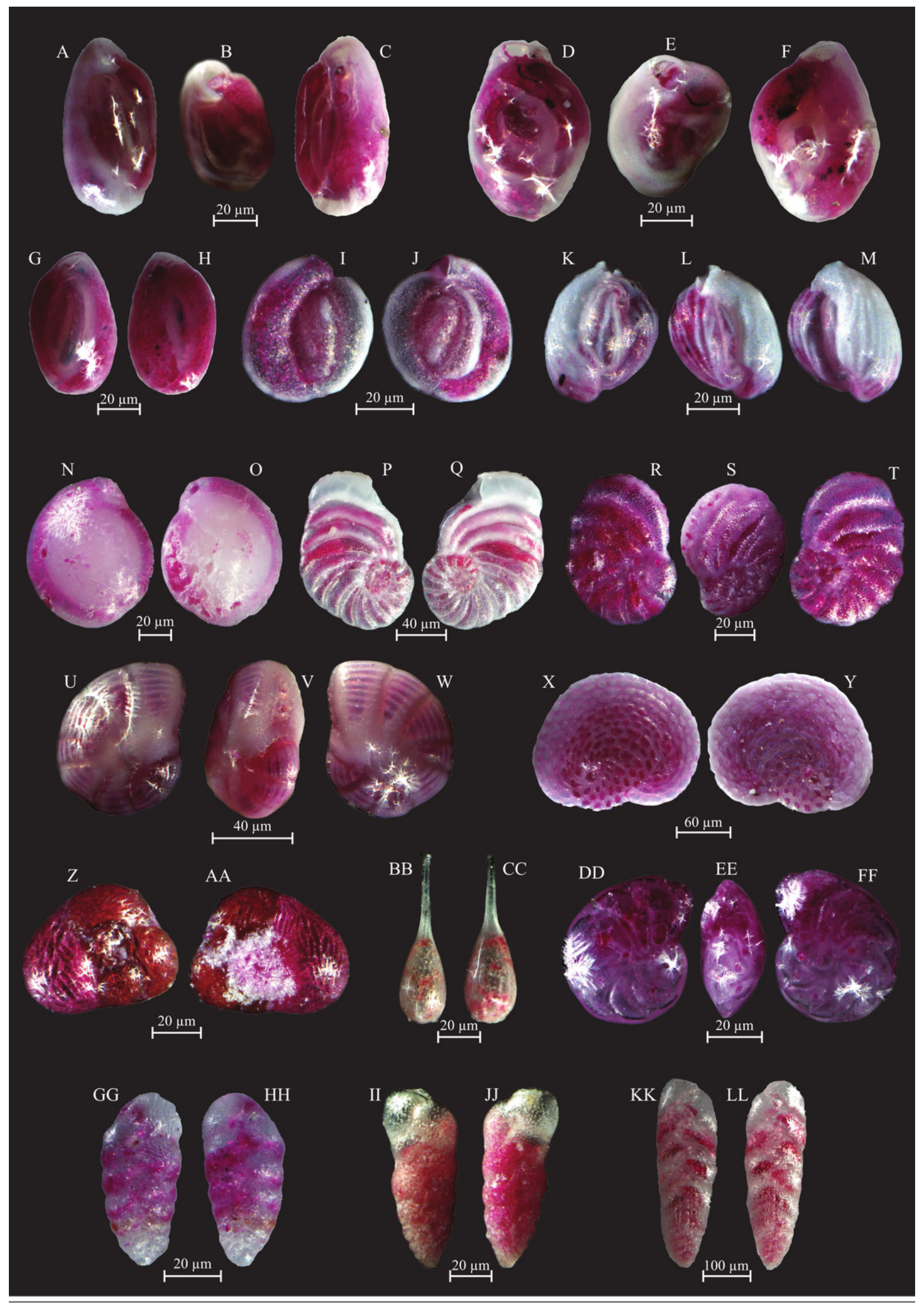

Peer) reviewing PDF | (2019:09:41510:1:1:NEW 29 Jan 2020) 


\section{Figure 9}

Images of selected foraminifera species.

A-B Bulimininella elegantissima (d'Orbigny, 1839): side view. C-D Bulimina elongata (d'Orbigny, 1846): side view. E-F Bulimina marginata (d'Orbigny, 1826): side view. G-H Floresina sp.: side view. I-J Fursenkoina acuta (d'Orbigny, 1846): side view. K-M Siphogenerina raphana (Parker and Jones, 1865): K, L side view; M top view. N-O Sigmavirgulina tortuosa (Brady, 1881): side view. P-R Abditodentrix rhomboidalis (Millet, 1899): P-Q side view; R top view. S-U Uvigerina sp.: S-T side view; U top view. V-W Uvigerina canariensis (d'Orbigny): side view; X-Y Valvulineria minuta (Parker, 1954): X umbilical view; Y spiral view. Z-AA Glabratella altispira (Buzas, Smith and Beem, 1977): Z spiral view; AA umbilical view. BB-CC Facetocochlea pulchra (Cushman, 1933): BB spiral view; CC umbilical view. DD-EE Rosalina bradyi (Cushman, 1915): DD spiral view; EE umbilical view. FF-GG Rosalina globularis (d'Orbigny, 1826): FF spiral view; GG umbilical view. HH-II Rosalina macropora (Hofker, 1951): HH spiral view; II umbilical view. JJ-KK Rosalina pellucida (Said, 1949): JJ spiral view; KK umbilical view. LL-MM Rosalina villardeboana (d'Orbigny, 1839): LL spiral view; MM umbilical view. NN-PP Discorbinella concinna (Brady, 1884): specimen with floating chamber, NN spiral view; 00 side view, PP umbilical view. 


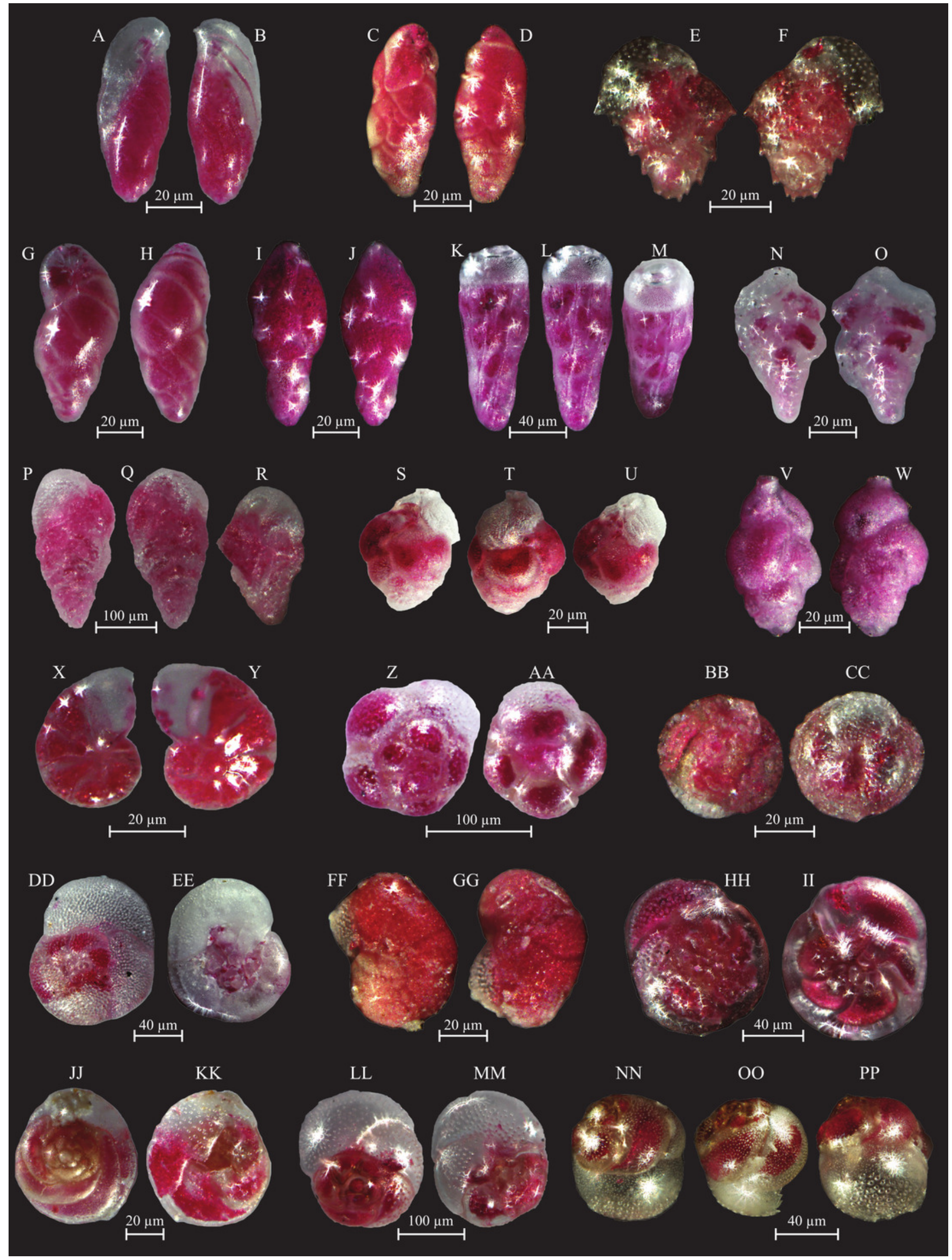




\section{Figure 10}

Images of selected foraminifera species.

A-B Rosalina bulloides (d'Orbigny, 1839): A spiral view; B umbilical view. C-D Cassidulina obtusa (Williamson, 1858): C spiral view; D umbilical view. E-F Discorbinella berthelotti (d'Orbigny, 1839): E spiral view; F umbilical view. G-H Cibicidella variabilis (d'Orbigny, 1826):

G spiral view; H umbilical view. I-J Gavelinopsis praegeri (Heron-Allen and Earland, 1913): I spiral view; J umbilical view. K-L Neoconorbina terquemi (Rzehak, 1888): K spiral view; L umbilical view. M-N Planorbulina mediterranensis (d'Orbigny, 1826): M spiral view; N umbilical view. O-P Planorbulina mediterranensis (d'Orbigny, 1826): O spiral view; P umbilical view. Q-R Cymbaloporetta bradyi (Cushman, 1915): Q spiral view; R umbilical view. S-U Asterigerinata mamilla (Williamson, 1858): S spiral view; T side view; U umbilical view. V-X Astrononion stelligerum (d'Orbigny, 1839): V, X spiral view; W side view. Y-Z Haynesina depressula (Walker and Jacob, 1798): Y spiral view; Z umbilical view. AA-BB Haynesina simplex (Cushman, 1933): AA spiral view; BB umbilical view. CC-DD Melonis affinis (Reuss, 1851): CC spiral view; DD umbilical view. EE-FF Nonion fabum (Fichtel and Moll, 1798): EE spiral view; FF umbilical view. GG-HH Nonionella turgida (Williamson, 1858): GG spiral view; HH umbilical view. II-JJ Noinionoides grateloupi (d'Orbigny, 1826): II spiral view; JJ umbilical view. 


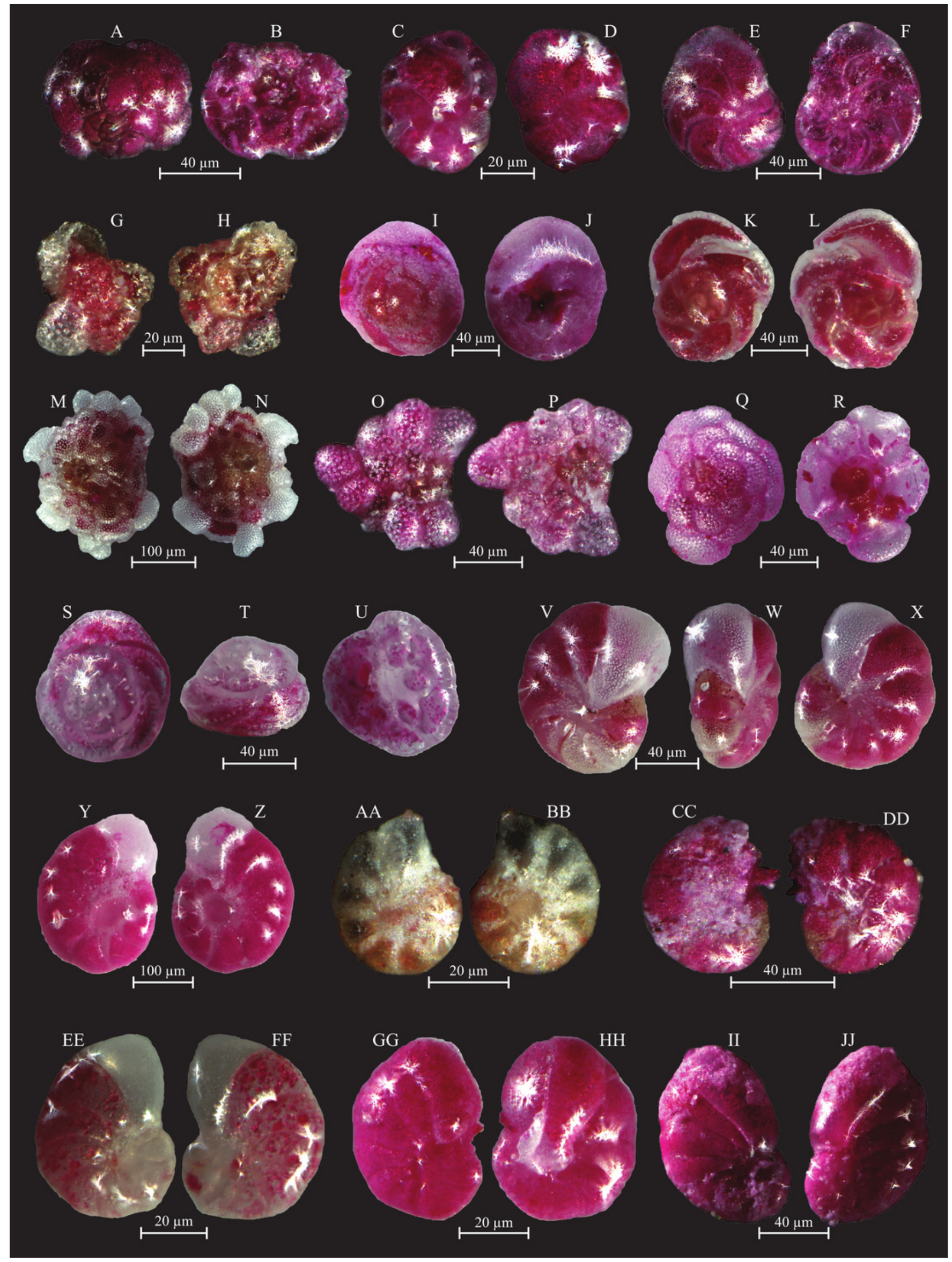




\section{Figure 11}

Images of selected foraminifera species.

A-B Ammonia beccarii (Linnaeus, 1758): A spiral view; B umbilical view.; C-D Ammonia convexa (Collins, 1958): C spiral view; D umbilical view. E-F Ammonia parkinsoniana (d'Orbigny, 1839): E spiral view; F umbilical view. G-H Ammonia tepida (Cushman, 1926): G spiral view; H umbilical view. I-J Amphistegina lessonii (d'Orbigny, 1826): I spiral view; J umbilical view. K-L Amphistegina lobifera (Larsen, 1976): K umbilical view; L spiral view. M-N Elphidium crispum (Linnaeus, 1758): spiral view. O-P Elphidium depressulum (Cushman, 1933): spiral view. Q-R Elphidium incertum (Williamson, 1858): spiral view.

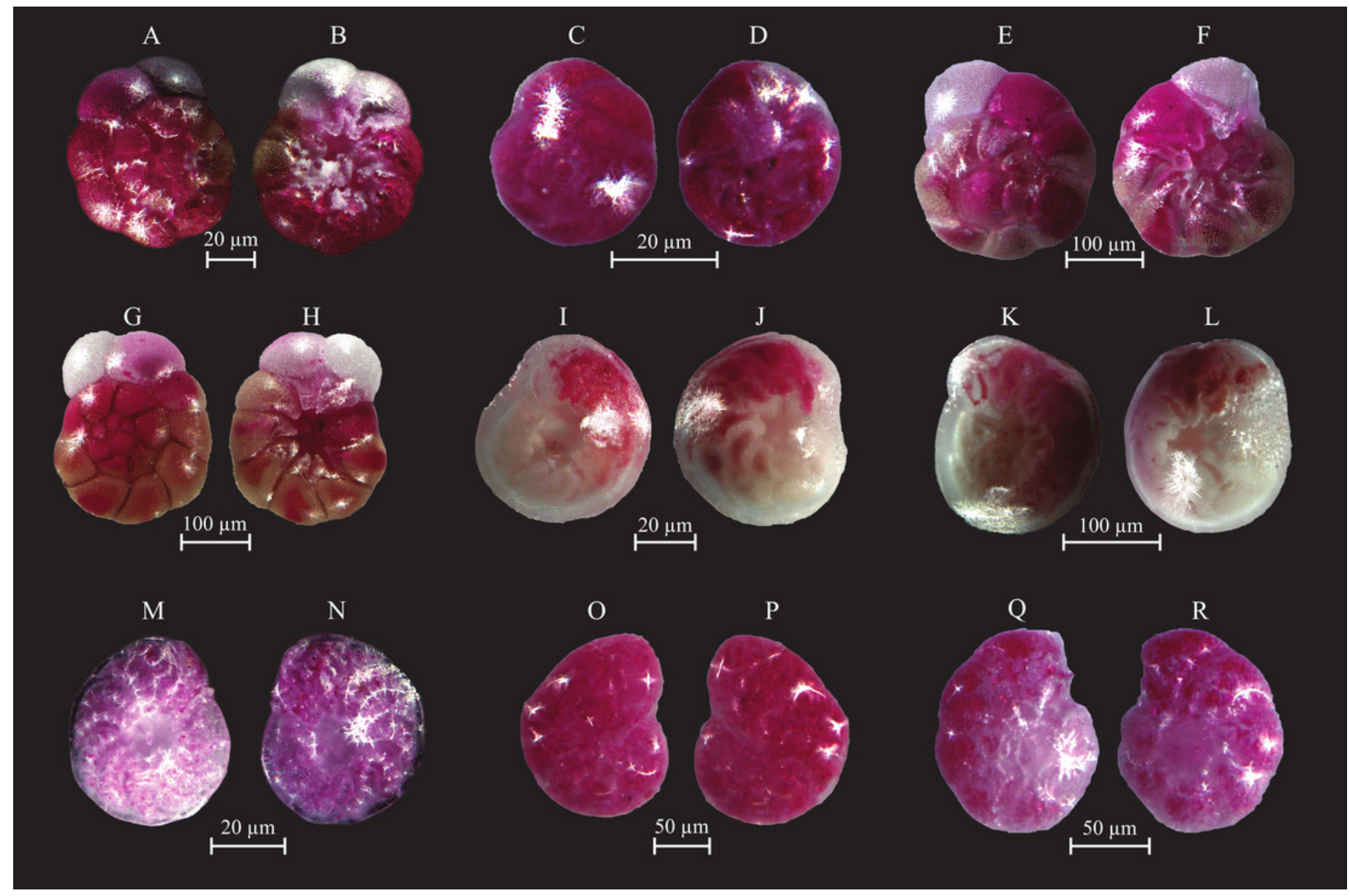


Table $\mathbf{1}$ (on next page)

Coordinates.

Geographic coordinates and water depths of the sampled stations. 


\begin{tabular}{|c|c|c|}
\hline Location & $\begin{array}{l}\text { Water } \\
\text { depth (m) }\end{array}$ & $\begin{array}{l}\text { Coordinates (latitude and } \\
\text { longitude) }\end{array}$ \\
\hline \multicolumn{3}{|c|}{ Gabes Transect } \\
\hline GSB-01 & 4.5 & N 335ㄴ'36.66" / E $10^{\circ} 6^{\prime} 34.74^{\prime \prime}$ \\
\hline GSB-02 & 7.3 & N 335'ㄷ⒉32" / E 10 7'11.76" \\
\hline GSB-03 & 9.6 & N 335' $9.54^{\prime \prime} /$ E $10^{\circ} 7 ' 44.10^{\prime \prime}$ \\
\hline GSB-04 & 9.1 & 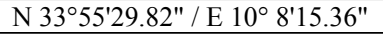 \\
\hline GSB-05 & 12 & N 335'ㄴㅇ.00" / E 10 8'46.92" \\
\hline GSB-06 & 12.9 & 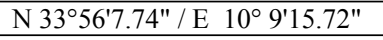 \\
\hline GSB-07 & 14.4 & 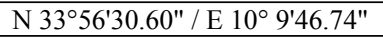 \\
\hline GSB-08 & 15 & N 335'ㄷ‥24" / E 10¹0'18.84" \\
\hline GSB-09 & 18 & N 335'ㄷ․ $16.20^{\prime \prime} /$ E $10^{\circ} 10^{\prime} 53.82^{\prime \prime}$ \\
\hline GSB-10 & 19.5 & N 335'ㄹ'29.34" / E 10²11'36.24" \\
\hline GSB-11 & 19.5 & 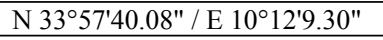 \\
\hline GSB-12 & 15,4 & N 335'ㄷ․64" / E 10²1'47.04" \\
\hline GSB-13 & 19.5 & 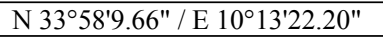 \\
\hline GSB-14 & 17.6 & 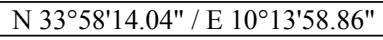 \\
\hline GSB-15 & 19.5 & 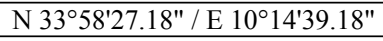 \\
\hline GSB-16 & 18 & 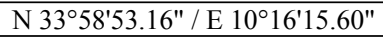 \\
\hline \multicolumn{3}{|c|}{ Djerba Transect } \\
\hline DJB-01 & 5.1 & 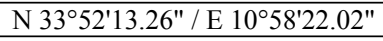 \\
\hline DJB-02 & 6.4 & N 335'ㄱ‥12" / E 1059'1.86" \\
\hline DJB-03 & 8.7 & N 335'ㄴㄱ.38" / E 1059'24.60" \\
\hline DJB-04 & 10.7 & N 3353'3.84" / E 1059'57.84" \\
\hline DJB-05 & 12.7 & $\mathrm{~N} 33^{\circ} 53^{\prime} 32.82^{\prime \prime} /$ E $11^{\circ} 0^{\prime} 15.30^{\prime \prime}$ \\
\hline DJB-06 & 12.2 & 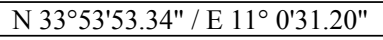 \\
\hline DJB-07 & 14 & 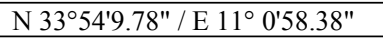 \\
\hline DJB-08 & 17.2 & 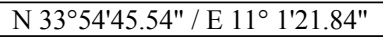 \\
\hline DJB-09 & 17.6 & 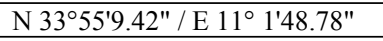 \\
\hline DJB-10 & 21.3 & 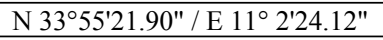 \\
\hline DJB-11 & 22 & $\mathrm{~N} 33^{\circ} 55^{\prime} 48.36^{\prime \prime} / \mathrm{E} 11^{\circ} 3^{\prime} 4.68^{\prime \prime}$ \\
\hline DJB-12 & 24 & 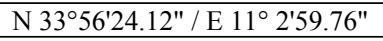 \\
\hline DJB-13 & 25,3 & 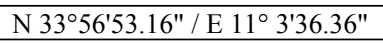 \\
\hline DJB-14 & 26 & N 335'ㄷ.64" / E $11^{\circ} 4^{\prime} 1.80^{\prime \prime}$ \\
\hline DJB-15 & 26.8 & 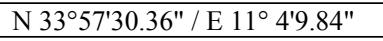 \\
\hline \multicolumn{3}{|c|}{ Coastal Stations } \\
\hline CTS-01 & $<1 \mathrm{~m}$ & $\mathrm{~N} 35^{\circ} 53^{\prime} 49.15^{\prime \prime} /$ E $10^{\circ} 35^{\prime} 45.79^{\prime \prime}$ \\
\hline CTS-02 & $<1 \mathrm{~m}$ & 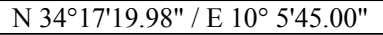 \\
\hline CTS-03 & $<1 \mathrm{~m}$ & N 34 2'15.84" / E 10²'9.36" \\
\hline CTS-04 & $<1 \mathrm{~m}$ & N 335'5.76" / E 10 7'13.92" \\
\hline CTS-05 & $<1 \mathrm{~m}$ & N 3341'57.90" / E 10²1'34.02" \\
\hline CTS-06 & $<1 \mathrm{~m}$ & $\mathrm{~N} 33^{\circ} 43^{\prime} 39.00^{\prime \prime} /$ E $10^{\circ} 44^{\prime} 22.50^{\prime \prime}$ \\
\hline CTS-07 & $<1 \mathrm{~m}$ & $\mathrm{~N} 33^{\circ} 51^{\prime} 34.62^{\prime \prime} / \mathrm{E} 10^{\circ} 44^{\prime} 41.40^{\prime \prime}$ \\
\hline
\end{tabular}




\section{Table 2 (on next page)}

Facies

Summary of the identified sedimentary facies along the Gabes and Djerba Transects (modified after El Kateb et al., 2018b). 


\begin{tabular}{|l|l|l|}
\hline Stations & Facies & Sediments \\
\hline GBS-01 to -02 & G1 & Dominant siliciclastic grains (e.g. quartz). \\
\hline GBS-03 & G2 & $\begin{array}{l}\text { Centimetric concretions of biogenic fragments partially } \\
\text { dissolved (e.g. bivalve, bryozoan, foraminifera and coral). }\end{array}$ \\
\hline GBS-04 to -06 & G3 & $\begin{array}{l}\text { Carbonate sand and biogenic fragments (bryozoans, } \\
\text { bivalves, gastropods and coral) }\end{array}$ \\
\hline $\begin{array}{l}\text { GBS-07 to -08, } \\
\text { GBS-10 to -16 }\end{array}$ & G4 & Fine sediment (clay) with centimetric biogenic fragments \\
\hline GBS-09 & G5 & $\begin{array}{l}\text { Very fine sediments (clay and silt) with rare biogenic } \\
\text { fragments. }\end{array}$ \\
\hline DJB-01 to -05 & D1 & Fine siliciclastic grains, Posidonia oceanica meadow \\
\hline DJB-06 to -08. & D2 & $\begin{array}{l}\text { Mix of sand and millimetric rounded biogenic poorly } \\
\text { preserved fragments }\end{array}$ \\
\hline DJB-11 to -15 & D3 & $\begin{array}{l}\text { Well-preserved biogenic fragments of bivalves, calcareous } \\
\text { algae, gastropods and bryozoans. }\end{array}$ \\
\hline
\end{tabular}

1 


\section{Table 3 (on next page)}

Statistical analyses.

SIMPER analysis using the Bray-Curtis similarity matrix on fourth-root transformed living (stained) benthic foraminifera abundance data from the Lesser Syrtis. The main species contributing to the similarity within the SIMPROF cluster groups are identified. Note: Only the taxa contributing $>5 \%$ to the within-group average similarity are shown. 


\begin{tabular}{|c|c|c|c|c|c|}
\hline Cluster & Species & $\begin{array}{l}\text { Average } \\
\text { Abundance }\end{array}$ & $\begin{array}{l}\text { Average } \\
\text { Similarity }\end{array}$ & Similarity/SD & Contribution \\
\hline \multirow{8}{*}{$B$} & Eggerelloüdes scabrus & 2,96 & 6,84 & 9,93 & 11,95 \\
\hline & Buliminella elegantissima & 2,43 & 5,65 & 9,28 & 9,87 \\
\hline & Brizalina striatula & 2,27 & 5,22 & 9,29 & 9,12 \\
\hline & Asterigerinata mamilla & 2,23 & 4,98 & 6,45 & 8,71 \\
\hline & Haynesina depressula & 1,67 & 3,56 & 4,11 & 6,22 \\
\hline & Ammonia tepida & 1,73 & 3,45 & 3,87 & 6,03 \\
\hline & Nonionides grateloupi & 1,43 & 3,00 & 5,20 & 5,25 \\
\hline & Bulimina marginata & 1,29 & 2,92 & 9,65 & 5,10 \\
\hline \multirow{7}{*}{$C$} & Trochamina inflata & 1,69 & 7,61 & $N / A$ & 13,68 \\
\hline & Rosalina vilardeboana & 2,04 & 7,27 & $N / A$ & 13,07 \\
\hline & Quinqueloculina laevigata & 1,25 & 5,78 & $N / A$ & 10,40 \\
\hline & Textularia conica & 1,54 & 5,78 & $N / A$ & 10,40 \\
\hline & Brizalina striatula & 1,48 & 4,86 & $N / A$ & 8,74 \\
\hline & Buliminella elegantissima & 1,28 & 4,86 & $N / A$ & 8,74 \\
\hline & Cornuspira involvens & 1,09 & 4,86 & $N / A$ & 8,74 \\
\hline \multirow{5}{*}{$D$} & Amphistegina lessonii & 2,90 & 4,55 & $N / A$ & 8,70 \\
\hline & Rosalina vilardeboana & 4,08 & 4,36 & $N / A$ & 8,33 \\
\hline & Planorbulina mediterranensis & 2,43 & 3,75 & $N / A$ & 7,17 \\
\hline & Rosalina macropora & 2,21 & 3,07 & $N / A$ & 5,86 \\
\hline & Mychostomina revertens & 1,79 & 2,72 & $N / A$ & 5,19 \\
\hline \multirow{6}{*}{$E$} & Rosalina macropora & 1,99 & 5,29 & 6,76 & 9,83 \\
\hline & Rosalina vilardeboana & 1,57 & 4,11 & 4,57 & 7,65 \\
\hline & Brizalina striatula & 1,55 & 4,01 & 4,76 & 7,45 \\
\hline & Amphistegina lessonii & 1,77 & 4,00 & 1,87 & 7,44 \\
\hline & Asterigerinata mamilla & 1,58 & 3,50 & 2,08 & 6,51 \\
\hline & Peneroplis pertusus & 1,41 & 2,85 & 1,36 & 5,30 \\
\hline \multirow{2}{*}{$F$} & Ammonia tepida & 1,49 & 13,12 & 8,79 & 36,52 \\
\hline & Brizalina striatula & 1,24 & 13,12 & 8,79 & 36,52 \\
\hline
\end{tabular}

